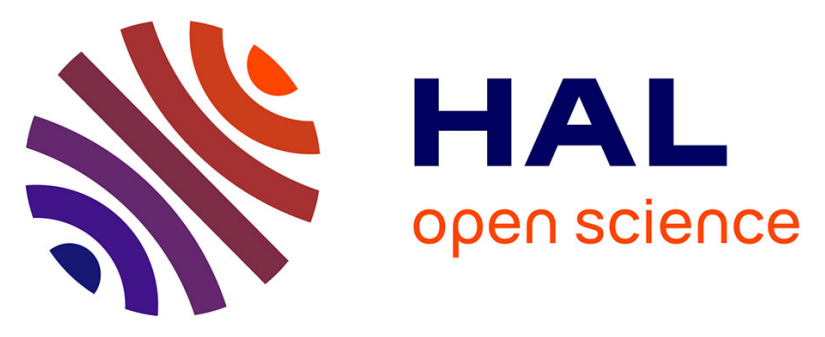

\title{
Ecology-based evaluation of groundwater ecosystems under intensive agriculture: A combination of community analysis and sentinel exposure
}

Pierre Marmonier, Chafik Maazouzi, Nicole Baran, Simon Blanchet, Amy Ritter, Maritxu Saplairoles, Marie-José Dole-Olivier, Diana M.P. Galassi, David Eme, Sylvain Dolédec, et al.

\section{To cite this version:}

Pierre Marmonier, Chafik Maazouzi, Nicole Baran, Simon Blanchet, Amy Ritter, et al.. Ecologybased evaluation of groundwater ecosystems under intensive agriculture: A combination of community analysis and sentinel exposure. Science of the Total Environment, 2018, 613-614, pp.1353-1366. 10.1016/j.scitotenv.2017.09.191 . hal-01637292

\section{HAL Id: hal-01637292}

\section{https://hal-univ-rennes1.archives-ouvertes.fr/hal-01637292}

Submitted on 24 Nov 2020

HAL is a multi-disciplinary open access archive for the deposit and dissemination of scientific research documents, whether they are published or not. The documents may come from teaching and research institutions in France or abroad, or from public or private research centers.
L'archive ouverte pluridisciplinaire $\mathbf{H A L}$, est destinée au dépôt et à la diffusion de documents scientifiques de niveau recherche, publiés ou non, émanant des établissements d'enseignement et de recherche français ou étrangers, des laboratoires publics ou privés.

\section{(이) $\$$}

Distributed under a Creative Commons Attribution - NonCommercial - NoDerivatives $\mid 4.0$ 
5 Ecology-based evaluation of groundwater ecosystems under

6 intensive agriculture: a combination of community analysis and

\section{7 sentinel exposure}

Marmonier Pierre ${ }^{1 \dagger}$, Maazouzi Chafik ${ }^{1}$, Baran Nicole $^{2}$, Blanchet Simon ${ }^{3,4}$, Amy Ritter $^{3}$,

14 Saplairole Maritxu ${ }^{5}$, Dole-Olivier Marie-José ${ }^{1}$, Galassi Diana M. P. ${ }^{6}$, Eme David ${ }^{1}$, Dolédec 15 Sylvain \& Piscart Christophe ${ }^{1,7}$.

Authors address:

$19{ }^{1}$ UMR-CNRS 5023 LEHNA, Université de Lyon, Université Lyon 1, 43 Boulevard du 11 20 Novembre 1918, 69622 Villeurbanne, France.

$21{ }^{2}$ Bureau de Recherches Géologiques et Minières, 3 Avenue Claude Guillemin, BP 6009, 2245060 Orléans Cedex 2, France.

$23{ }^{3}$ Centre National de la Recherche Scientifique (CNRS) ; Station d'Ecologie Expérimentale 24 UMR 5321, F-09200 Moulis, France.

$25{ }^{4}$ Centre National de la Recherche Scientifique (CNRS), Université Paul Sabatier, École 26 Nationale de Formation Agronomique (ENFA); UMR5174 EDB (Laboratoire Évolution \& 27 Diversité Biologique), 118 route de Narbonne, F-31062 Toulouse cedex 4, France.

$28{ }^{5}$ Bureau de Recherches Géologiques et Minières, 3 rue Marie Curie, B.P. 49, 31527

29 Ramonville-Saint-Agne, France.

$30{ }^{6}$ Department of Life, Health \& Environmental Sciences, University of L'Aquila, 67100

31 L'Aquila, Italy.

$32{ }^{7}$ Present address: UMR-CNRS 6553 ECOBIO, Campus de Beaulieu, Bâtiment 14A, 263

33 Avenue du General Leclerc, 35042 Rennes, France.

$34{ }^{\dagger}$ Corresponding author: Pierre Marmonier 
ABSTRACT

37 Ecological criteria are needed for a comprehensive evaluation of groundwater ecosystem health including biological components along with the physical and chemical properties that are already required by European directives. We evaluated the performance of two different methodological approaches for an ecological assessment of groundwater ecosystems in two alluvial plains (the Ariège and Hers rivers, southwestern France) varying in agriculture intensity (from grassland to crop rotation including corn and sunflower, and to corn monoculture). In the first approach, we analysed the composition of invertebrate assemblages (only obligategroundwater crustaceans, i.e. stygobite) sampled in 28 wells located in 6 sectors differing in their agriculture contexts. Abundance, species richness, and assemblage composition did not significantly vary at the sector scale, but significantly changed with agriculture practices or urbanization around the well. These community metrics are thus not always eligible as ecological indicators. In the second approach, we tested an in situ exposure of sentinel organisms in the groundwater to quantify their response to the environmental conditions. We used the epigean and local amphipod species Gammarus cf. orinos as a sentinel species. Amphipods (30 individuals in each of 10 wells) were exposed for one week to the in situ conditions at two seasons with high and low transfer of pollutants. An EcoPhysiological Index (EPI) synthetizing the survival rates and energetic storage decreased in wells with low oxygen and high nitrate concentrations, but only during the high pollution transfer period. We also found evidence that atrazine-related compounds may negatively impacted sentinel health whatever the season. These results highlight that use of sentinel species in experiments may have a major applied value for groundwater ecosystem assessment.

61

Key words: Subterranean ecosystems, Crustaceans, Stygobite, Sentinel organisms, Herbicides, Triazines. 


\section{Introduction}

67 Facing the development of growing human populations and activities, a major challenge for the future will be to maintain groundwater ecosystem health, i.e. the capacity of the groundwater ecosystem to sustain its structural and functional integrity and sustainably provide appropriate services (Korbel \& Hose, 2011). Among the many services that groundwater ecosystems provide to humans (Tomlinson et al., 2007; Boulton, 2009) the most valuable are drinking water supply (van der Gun, 2012) and water use for irrigation for both traditional and intensive agriculture (Burke, 2003; Zektser \& Everett, 2004). Upwelling groundwater may also influence stream and wetland conditions through water level, temperature and water quality (Ramsar Convention Secretariat, 2010). Groundwater quality is under threat in many areas due to agriculture practices (Bohlke, 2002; Legout et al., 2005, 2007: Martin et al., 2006, European Environmental Agency, 2010; Lapworth et al., 2012; Di Lorenzo \& Galassi, 2013), industrial development and urbanisation (Datry et al., 2004, 2005; Foulquier et al., 2010, 2011; Lerner \& Barrett, 1996; Trauth \& Xanthopoulos, 1997; Di Lorenzo et al., 2012). Reliable evaluations of groundwater ecosystem health have thus become essential for the proposal and the establishment of restoration strategies (Boulton, 2005; Griebler et al., 2014).

In Europe, groundwater quality is still evaluated based on physical, chemical and hydrological characteristics (European Commission, 2006), although the inclusion of ecological criteria has been repeatedly advocated (Danielopol et al., 2004, 2006b, 2008; Hancock et al., 2005; Hahn, 2006; Tomlinson et al., 2007; Steube et al., 2009; Griebler et al., 2010). The few existing ecological indicators of groundwater ecosystem health consist of the examination of parameters describing invertebrate or microbial communities (Mösslacher, 2000; Danielopol et al., 2006a; Hahn, 2006; Gutjard et al., 2013; Griebler et al., 2010; Stein et al., 2010; Korbel \& Hose, 2011; Gutjahr, 2013; Griebler et al., 2014) or biofilm growing on artificial substrates (Williamson et al., 2012; Mermillod-Blondin et al., 2013). More recently, the use of sentinel invertebrates caged inside groundwater wells has been proposed to avoid confounding effects related to local characteristics (e.g. depth and characteristics of the well, variability in the exchange of water between well of groundwater) and 
may lead to misinterpretation of the relationships with ecosystem quality (Marmonier et al., 2013).

Here, we compared the performance of two ecological methods that evaluate the quality of groundwater ecosystems exposed to intensive agriculture in southwestern France. (1) The composition and structure of stygobite crustacean assemblages of 28 wells were studied in different agricultural contexts in the Ariège and Hers alluvial plains. We expected that water quality (influenced mainly by agriculture practices) would be significantly associated to decreases in abundance, species richness or to changes in the composition of hypogean crustacean assemblages. We tested this hypothesis for six different sectors of the plains with contrasted agriculture characteristics and for each well considered individually. (2) We then used sentinel crustacean species (a local epigean amphipod Gammarus cf orinos,) caged in a subset of 10 wells in the same area, immediately after (July) and three months after (September) the end of corn herbicide spreading (mostly S-metolachlor). The survival rate and the level of energetic consumption were determined after one week and expressed as the Ecophysiological Index (EPI, Marmonier et al., 2013) to quantify the stress endured by the sentinels during the exposure period. We expected that agriculture-derived contamination of groundwater would induce a significant decrease in sentinel health.

\section{Material \& methods}

\subsection{Study area}

The Ariège and Hers alluvial plains are located in southwestern France and encompass a $540 \mathrm{~km}^{2}$ surface area. The studied sector of the Ariège alluvial plain (Fig. 1) is located between Varilhes (South) and Portet-sur-Garonne (North). The Hers plain is located between Mirepoix (South) and Cintegabelle (North) where the Hers River joins the Ariège River. The area is underlain by Aquitanian (Miocene) and Stampian (Oligocene) molasse deposits. The Ariège River alluvium was deposited on the molasse in five distinct terraces with very similar grain size compositions. The sand-and-gravel alluvium of the lower terrace and the lower plain is a continuous unconfined aquifer that is hydraulically connected to the Ariège and Hers Rivers, 
132 feeding them during much of the year, especially in summer. The unsaturated zone is generally less than $10 \mathrm{~m}$ thick.

The region is characterized by intensive agriculture, the major crop being corn and sunflower. The land use analysis (Fig. 1A) was established using satellite images from 4 dates (winter, spring, summer, and fall 2008) where six land use were defined (forest, grassland, corn-sunflower, other cultures, urbanized area and waterbodies; using Maplnfo 8.5.1B囚). The area of intense agriculture (red colour dominant in Fig. 1A) showed strong degradation in the groundwater quality. This degradation is documented for a long time by the Adour-Garonne Water Agency that manages the monitoring according to the Water Framework Directive (European Commission, 2000; especially for nitrate and pesticides concentrations), or by a reinforced monitoring (Amalric et al., 2013). In this perspective, a preliminary large-scale study was performed in 2008 on groundwater chemistry, with a set of 144 wells and springs where nitrate concentrations were measured. These results showed that 71 points (i.e. $49 \%$ ) were above the European standard limits (50 mg/L) established by the European Commission (2006), 22 of which (i.e. 15\%) were over 100 mg/L. Wells with high nitrate concentrations were located in an area dominated by corn and sunflower productions.

According to lithology, hydrogeology, and land use, the studied area has been

153 divided into six sectors with distinct human activities and different degrees of 154 groundwater alteration (Fig. 1B). The upstream part of the Hers (hereafter HUp) and 155 Ariège (AUp) alluvial plains were dominated by grassland with forest patches (Table 156 1, percentages of grassland were higher in HUp and AUp than downstream sectors, 157 ANOVA $F_{4,23}=3.157, p=0.026$, see below for statistics). In these two upstream 158 sectors, groundwater was characterized by low to medium nitrate concentrations 159 (Table 1). In the downstream part of the Hers (HDw) and a first intermediate sector of 160 the Ariège plain (Alnt1) where land use was strongly dominated by corn and 161 sunflower productions $\left(F_{4,23}=6.584, p=0.0007\right.$ for corn, $F_{4,23}=3.282, p=0.023$ for other 162 culture such as sunflower), groundwater was characterized by high nitrate 163 concentrations. A second intermediate sector occurred downstream of the Hers164 Ariège confluence (Alnt2) with a more diverse agricultural land use, but still very high 165 nitrate concentrations in groundwater. Finally, the downstream sector of the Ariège 
166 plain (ADw) was characterized by increasing urbanisation, decreasing agriculture, and decreasing nitrate concentrations in wells. These six sectors were used to determine the distribution of available sampling wells.

\subsection{Water quality and invertebrate assemblages}

171 Invertebrate assemblages and water quality were studied in 28 wells (Fig. 1B) 172 sampled in January 2012 before the beginning of irrigation and other farming 173 activities but also before the beginning of the water quality survey. Wells were distributed as evenly as possible in the 6 sectors defined on a land use basis. In the Hers alluvial plain, six wells were located in the upstream sector ( $\mathrm{H} 1$ to $\mathrm{H} 6$ in $\mathrm{HUp}$ ) and six others downstream ( $\mathrm{H} 7$ to $\mathrm{H} 12$ in $\mathrm{HDw}$ ). Along the Ariège River, 16 wells were distributed from upstream to downstream: $A 1$ to $A 4$ in the sector AUp, A5 to A8 in Alnt1, A9 to A12 in Alnt2, and A13 to A16 in ADw. Land-cover around each well (buffer of $3 \mathrm{~km}^{2}$ ) was established with Maplnfo 8.5.1B using the 6 land-cover types mapped in Fig. 1A.

The fauna was sampled within these wells using a method derived from the BouRouch technique (Bou \& Rouch, 1967): 40 litres of water and fine sediment were pumped by disturbing the bottom of the well with a long and weighted semi-rigid tube connected to a hand-pump (Malard et al., 2003). Water quality was reduced to in situ measures: temperature, electrical conductivity at $25^{\circ} \mathrm{C}, \mathrm{pH}$, and dissolved oxygen, using a HACH-LANGE portable apparatus (HQ40d Multiparameter, Düsseldorf, Germany) on the last litre of pumped water. The $40-\mathrm{L}$ samples were then filtered through a $100 \mu \mathrm{m}$ mesh net to retain fauna that was immediately preserved in $96^{\circ}$ alcohol. The analysis of invertebrate assemblages was restricted to stygobionts for comparison with previous studies performed in 1999 by Dumas (2000) and in 2003 by Janiaud (2004). Amphipods, isopods, copepods, and ostracods were identified to species level using morpho-anatomical criteria.

195 For Amphipods, morphological identification was completed by molecular barcoding 196 to ensure morphological identifications and to identify damaged/young individuals. 197 Briefly, DNA was extracted from all individuals following standard protocols. Nuclear 198 28S rDNA fragments measuring about 830-870 bp were amplified using the primers 
200 from Fiser et al (2008). Sequences were aligned using Bio Edit Sequence Alignment 201 Editor (Hall 1999). Phylogenetic evolutionary analysis was conducted using 202 maximum parsimony and bootstrapping using Mega version 5 (Tamura et al. 2011), 203 and resulting phylogenetic trees were used to delimitate the main species in the area. 204 Because sequencing failed for most individuals (mainly because of poor DNA 205 quality), we used a shorter fragment (180-215 bp) allowing discrimination among the 206 main species groups found in this area through genotyping. We used the primers 5'207 'TTGAGCCTGTGGGTGAC-3' and 5' GCCTGCACCAAGATTTAACC-3' to amplify 208 sequences of unique size for each species, which allowed identifying species based 209 on the size of the peaks. We used the size of the peaks to distinguish a "Niphargus 210 kochianus" species group from the three other taxa (N. ciliatus, N. foreli, and 211 Niphargus sp., smaller-sized fragments). These peaks were scored in the program 212 Gene Mapper version 5 (Applied Biosystems 2012). Although not perfect, this 213 genotyping approach allowed for verification of most morphological identifications. 214 We used 5-20 ng of genomic DNA and QIAGEN® Core PCR Kits (Qiagen, Valencia, 215 CA, USA) to perform PCR amplifications (recipes available upon request). PCR 216 products were revealed on an ABI PRISM ${ }^{\mathrm{TM}} 3730$ Automated Capillary Sequencer 217 (Applied Biosystems, Foster City, CA, USA).

\subsection{Water quality and sentinel exposure}

Ten wells were selected for the cage experiment with sentinel amphipods exposure in groundwater (Fig. 1C). In order to evaluate the sensitivity of the method, the exposure experiment was carried out twice with identical methods: (1) three months after the end of corn herbicide spreading, during the low water period of a rather dry year (September 2012) resulting in low transfer of pollutants (hereafter 'low transfer period') and (2) just after the end of pesticide application, during high water period of a rather wet year (July 2013) resulting in high transfer of pollutants (hereafter 'high transfer period'). The 10 wells were distributed across 5 of the 6 sectors defined from 228 land use (Fig. 1C).

230 Water quality was evaluated by field measurements $(\mathrm{pH}$, electrical conductivity, 231 temperature, redox potential and dissolved oxygen) and laboratory analyses: water 232 samples were analysed by ICP-AES for $\mathrm{Ca}^{2+}, \mathrm{Na}^{+}, \mathrm{K}^{+}, \mathrm{Mg}^{2+}$ (uncertainty $5 \%$ ), ion 233 chromatography for $\mathrm{Cl}^{-}, \mathrm{SO}_{4}{ }^{2-}, \mathrm{NO}_{3}{ }^{-}$(uncertainty less than $10 \%$ ) and potentiometric 
234 method according to $\mathrm{N}$ EN ISO 9963-1 for $\mathrm{HCO}_{3}{ }^{-}$and $\mathrm{CO}_{3}{ }^{2-}$ (uncertainty 5\%). All 235 pesticides and metabolites were determined with a Waters UPLC system coupled to 236 a Waters micromass MSMS (Waters Quattro-Premier XE/Q) after a solid phase 237 extraction. Chromatographic separation for neutral and ionic compounds was done 238 with a Waters Acquity UPLC BEH C18 column. Internal standards were used for 239 calibration. Method details are reported in Amalric et al. (2013) and the list of 240 measured compounds with their detection limit are presented in appendix 1.

242 As local densities of stygobite amphipods were very low in the studied area, the 243 selected sentinel species was an epigean amphipod (Gammarus of orinos) living at 244 the surface/ground water interface (in springs and small streams). Sentinels were 245 captured in the field in a neighbourhood brook, kept for one week in the laboratory 246 and then caged in situ. Cages consisted of stainless iron netting cylinders $(6 \mathrm{~cm}$ 247 height $\times 1.5 \mathrm{~cm}$ diameter; $200 \mu \mathrm{m}$ mesh) and closed by two plastic caps at each end 248 (Marmonier et al., 2013). Six such cages, each containing five G. cf orinos 249 individuals, were placed in each well in both low and high transfer periods (i.e. 30 250 individuals per well and exposure period). The cages were retrieved after one week 251 of exposure. Three ecophysiological parameters were measured on the specimens: 252 (1) the survival rate, (2) glycogen and (3) triglyceride body concentrations. Three sets 253 of three individuals (i.e. 9 individuals) found alive were frozen-dried at retrieval time 254 and used for each biochemical analysis at each occasion (period/well). Glycogen and 255 total triglyceride concentrations were measured by standard enzymatic methods 256 using specific test combinations, according to Hervant et al. (1995, 1996). Ad hoc 257 Sigma-Aldrich (France) glucose HK and GPO Trinder kits were used to determine 258 glycogen and triglycerides, respectively. Glycogen concentration was expressed as $259 \mathrm{mg}$ of glycosyl, and triglyceride concentration was expressed as $\mathrm{mg}$ of glycerol. All 260 assays were performed in an Uvikon 940 recording spectrophotometer (Kontron Inc., 261 Germany) at $25^{\circ} \mathrm{C}$.

\subsection{Data analyses}

264 Statistical analyses were performed at the scale of the six sectors defined in the Ariège and Hers alluvial plains and at the scale of each individual well. At the sector scale, species richness, total abundances of stygobionts and abundances of the most frequent species were compared between the six sectors (with wells as 
replicates) using one-way ANOVA (significant level of $p=0.05$ ) after the data were $\log _{10}(x+1)$ transformed to reach a normal distribution. The quasi balanced design $(n$ $=6,6,4,4,4$, Table 1) renders the ANOVA quite robust despite the low degree of replication (Quinn \& Keough, 2002; Zar, 2009). At the scale of the individual well,

272 faunal characteristics (stygobiont abundances and richness) were correlated to water 273 chemistry (i.e. field measured parameters) and land use around the well and 274 regression curve calculated when correlations were significant $(p=0.05)$. The assemblage composition was analysed using Non Metric Multidimensional Scaling using the Bray-Curtis dissimilarity index (NMDS, Legendre \& Legendre, 1998). Chemical and land use characteristics around the well were fitted to the NMDS ordination to allow visualization for testing which of them contributed significantly to the NMDS ordination. Analyses were performed using the $R$ statistical software $(R$ core Development Team, 2013), using the vegan R package (Oksanen et al., 2012).

The Ecophysiological Index (EPI, Marmonier et al., 2013) was calculated in the sentinel study on surviving animals using the following equation:

$$
\mathrm{EPI}=\text { Survival rate } x([\mathrm{Gly}] /([\text { Tri] }+[\text { Gly }]))
$$

where the sentinel survival rate (as \%) is combined with the state of their energetic stores as a ratio between glycogen content (noted as [Gly]), which is the first energetic store substance used in response to acute stress (Maazouzi et al., 2011), and their total body stores, as estimated from the sum of triglyceride (noted as [Tri]) and glycogen concentrations. In order to avoid seasonal differences in animal energetic store before the experiment, a ratio was calculated between EPI of sentinel individuals exposed in wells and EPI of reference sentinels, i.e. stress-free animals caged at the laboratory in synthetic water (see Nogaro et al, 2008). The in situ / laboratory ratio for the EPI can vary between values close to 0 (high impact of well water on exposed sentinels) to values close to 1 or in some rare cases slightly above 1 (meaning no difference between exposed and reference organisms).

Linear correlations were calculated between EPI and water chemical characteristics (oxygen, nitrate, and herbicide concentrations). We additionally ran a multiple regression to specifically test (i) the chemical variables influencing this ratio and (ii) whether or not these influences were constant over the two experimental sessions. 
"replicates") was low compared to the total number of explanatory variables, we

303 performed a regression on PCA axes (Jollifre, 1982). Specifically, we ran a PCA on 304 water quality variables (18 variables in total, see Table 4). We gathered the PCA 305 coordinates of each well (per experimental session) along the first-five PCA axes 306 (these axes summarized more than $82 \%$ of the total variation, see Table 4 ). This lead 307 to a total of five synthetic explanatory variables correlated to the actual variables (see 308 Table 4 for correlation values between each actual variable and each PCA axis). 309 Then we built a mixed linear model with EPI ratio as the dependent variable and the 310 five synthetic variables and the experimental session (categorical) as explanatory 311 variables. To test for temporal consistency, two-way interactions between 312 experimental session and each of the other variables was accounted for in the 313 model. The well identity was included as a random effect to account for temporal 314 pseudo-replication. This full model was reduced by building all possible models (i.e. 315 all combination of variables) and ranking them according to their Akaike Information 316 Criteria (AIC). The best-reduced model was that having the lower AIC.

\section{7}

\section{3. Results}

\subsection{Stygobite assemblages}

3212,691 stygobite crustaceans, representing a total of 14 taxa were collected in situ on 322 a total of 12,155 individuals and 36 taxa sampled. Six species were amphipods 323 (genera Niphargus and Salentinella, Table 2), four were copepods and four were 324 ostracods. Molecular identifications reduced the number of otherwise unidentified specimens of amphipods by 40\% (65 individuals remained unidentified because of small size, body degradation during pumping and DNA amplification failure). The

327 spatial distribution of stygobionts was markedly heterogeneous. Abundances varied 328 from 0 (the $A 1, A 2, A 6, A 13$ and $A 15$ wells) to more than 100 individuals per sample 329 (in H8, Fig. 2), and taxonomic richness ranged from 0 to 5 species (in wells $A 12, H 3$, $330 \mathrm{H} 5$ and $\mathrm{H} 6)$.

332 At the sector scale, the abundances in wells located in the Hers and the Ariège 333 alluvial plains differed significantly $\left(F_{4,23}=5.136, p=0.0028\right)$ : the assemblages 334 sampled along the Hers (HUp and HDw) were more abundant than those of the 335 Ariège (except for wells $\mathrm{A} 10$ and $\mathrm{A} 12$ in the Aint2 sector). This difference was 
observed whatever the dominant land use of the sector $\left(F_{1,8}=35.32, p=0.0003\right.$ between HDw and ADw dominated by intense agriculture). Similarly, species richness significantly differed among alluvial plains $\left(F_{4,23}=3.56, p=0.0164\right)$ : higher species richness was measured in wells located along the Hers (Hup and HDw sectors) than in wells distributed along the Ariège (except in Int2). Again this difference was observed in all types of agriculture practices.

At the well scale, no significant correlation was detected between abundance or species richness and the distance between wells and the two rivers ( $p>0.05$ for both distances to Ariège and Hers Rivers for $\mathrm{A}$ and $\mathrm{H}$ wells, respectively) nor with the upstream-downstream location of the well along the rivers $(p>0.05$ for both Ariège and Hers Rivers). In the same way, no significant correlation was found between these assemblage characteristics and the water characteristics (i.e. dissolved oxygen, temperature, or electric conductivity; in all cases $\left.r^{2}<0.08, p>0.05\right)$. In contrast, the abundances and species richness of stygobite crustaceans significantly changed with the human activities around the well. Abundances increased with the percentage of agriculture with highest values between 30 and $60 \%$ followed by a slight decrease $\left(r^{2}=0.158, p=0.018\right.$, Fig. 2B). This change in abundances was mainly due to an increase in the number of $N$. kochianus $\left(r^{2}=0.125, p=0.030\right)$. Inversely, species richness decreased with the percentage of urban area around the well $\left(r^{2}=0.134, p=0.027\right.$, Fig. 2C). In all cases, the correlation coefficients obtained were weak and a large dispersion of wells was observed for high values of abundances and species richness.

The NMDS analysis (Fig. 3, stress=0.054) highlighted some differences in the composition of the assemblages. A large number of wells were grouped close to the origin of the NMDS1 and NMDS2 axes, because of high abundances of N. kochianus and, to a lesser extent, of $N$. ciliatus in most of the wells (Table 2 and Fig. 4). This group of wells suffered very different anthropic activities, from traditional agriculture with dominant grasslands (A3 and A4 from the AUp sector, $\mathrm{H} 2, \mathrm{H} 5, \mathrm{H} 6$ from the HUp sector) to intensive agriculture with corn as monoculture (A7, A14 from Aint sectors or $\mathrm{H} 7$ to $\mathrm{H} 12$ from the HDw sector). Similarly, the six wells excluded from the analysis because of the absence of stygobite crustaceans (reported in a box in Fig. 3A) were located in sectors dominated by either traditional (A1, A2) or intensive agriculture 
370 (A9, A13, A15). Two wells were located out of this central group on the most negative 371 side of NMDS1 ( $\mathrm{H} 8$ and H9) because of the absence of $N$. kochianus and the 372 occurrence of two rare species (Diacyclops clandestinus and Pseudocandona sp3, 373 Fig. 3B and 4). On the opposite side of NMDS1, the well H4 was isolated because of 374 the occurrence of the rare Diacyclops belgicus (Fig. 3B and 4). Considering 375 environmental factors, NMDS1 was correlated with the percentage of grassland on 376 the positive side and the percentage of cultivated land on the negative side (Table 3). 377 Similarly, three wells (A7, A8 and A11) were located on the most negative side of the 378 NMDS2 axis for similar reasons: low abundances of $N$. kochianus and high 379 abundances of Salentinella (both S. major and S. petiti, Fig. 3B). This second axis 380 was structured by wells surrounded by high percentage of forest (Fig. 3C), but this 381 correlation was not significant (Table 3). Finally, the scores of 16 wells located in the 382 Ariège alluvial plain along the NMDS2 axis were positively correlated to the distance 383 to the river $\left(r^{2}=0.4379, p=0.038\right)$ : the well $A 11$ located at $100 m$ of the river and the 384 well $A 8$ at $600 m$ yielded assemblages with only few or no $N$. kochianus nor $N$. 385 ciliatus, but populations of Salentinella (Fig. 4). No significant relationship between distance to the river and fauna was observed for the Hers River.

\subsection{Sentinels exposure}

The analyses of pesticides and metabolite concentrations confirm that pollution was lower during the low transfer period (maximum total herbicide concentration of 2.89 $\mu \mathrm{g} / \mathrm{L}$ and $2.18 \mu \mathrm{g} / \mathrm{L}$ for S-metolachlor, an herbicide widely used, and its ESA and OXA metabolites, the predominant herbicide molecules) than during the high transfer period (maximum total herbicide of $9.59 \mu \mathrm{g} / \mathrm{L}$ and $9.2 \mu \mathrm{g} / \mathrm{L}$ for S-metolachlor and its metabolites). Weak EPI index differences were observed during low transfer period whereas an upstream-downstream gradient was evident during high transfer period (Fig. 5). The EPI was close to 1 (i.e., similar to the uncontaminated laboratory controls) in the upstream wells (A1, A2, A3, A4) whereas low values occurred in the downstream wells ( $\mathrm{H} 9, \mathrm{H} 10, \mathrm{~A} 8$ and $\mathrm{A} 10)$. During the high transfer period, the EPI values were positively correlated to dissolved oxygen $\left(r^{2}=0.420 ; p=0.021\right)$ and negatively correlated to nitrate concentrations $\left(r^{2}=0.370 ; p=0.031\right.$; Fig. 6). These correlations were not observed during the low transfer period (Fig. 6), despite a similar range of variation in dissolved oxygen and nitrate concentrations. We did not 
404

405

406

407

408

409

410

411

412

413

414

415

416

417

418

419

420

421

422

423

424

425

426

427

428

429

430

431

432

433

434

435

436

agriculture around the wells, the total pesticides concentrations nor each pesticide considered separately (in all cases $p>0.05$ ). In contrast when all chemical parameters were considered together, the best-reduced model $\left(\mathrm{AIC}=7.4, W_{i}=46.0 \%\right)$ included PCA axes 1, 2 \& 5 (Table 4). In the best-reduced model, the relationships between of PCA axes 2 and 5 and EPI varied between the two experimental sessions as there were significant two-way interactions between PCA axes 2 and 5 and experimental session. These interactions suggest that the effects of the variables associated with these two axes were not consistent over time. Contrastingly, the relationship between PCA axis 1 and EPI was negative both during the first and second experimental sessions, which demonstrated a highly consistent effect (Fig. 7). The strong correlation of this PCA axis with atrazine-related compounds (i.e. atrazine, deisopropylatrazine, and DEA with correlation to PCA axis 1 above 0.87 , Table 4) suggests a potential relationship between EPI decrease and the combination of these pesticides and metabolites.

\section{Discussion}

The need for ecological indicators for groundwater quality evaluation has been advocated by several authors to warn about the sensitivity of these systems to human activities (e.g. Marmonier et al., 1993; Danielopol et al., 2004; Griebler et al., 2010). In our study, indicators based on crustacean assemblage composition were combined with in situ sentinel exposure and brought contrasting results to the fore.

\subsection{Stygobite assemblages and water quality}

The distribution of the crustacean assemblages was very heterogeneous in the two alluvial plains and significantly but weakly related to water quality and human activities. At the sector scale (when wells are grouped in land use based sectors), the abundances, species richness and composition of assemblages were poorly related to agricultural practices and the resulting water quality (based on $\mathrm{pH}$, dissolved oxygen, electrical conductivity and nitrate concentrations). Similar patchy distribution of groundwater fauna was already reported in less impacted environments, such as the Danube and Rhône floodplains (Danielopol, 1989, Dole \& Mathieu, 1984), or in glacial streams (e.g. Malard et al., 2002, 2003) and springs (Fiasca et al., 2014). 
When the wells were considered individually, no link was observed between faunal characteristics and local water chemistry. During our first survey of the stygobite assemblages in January 2012, the water quality assessment was limited to simple parameters (i.e. temperature, $\mathrm{pH}$, dissolved Oxygen, electric conductivity) and did not include the total array of parameters as measured during the sentinel exposure. In contrast, significant correlations were observed between abundances, species richness and the land use around the well (agriculture and urban area respectively). NMDS analysis of the assemblage composition showed a rather similar trend (for the percentages of cultivated land and grassland). Even if this statistically significant trend was weak, the local human activities around the well explained at least a part of the stygobite assemblage composition and our first prediction was thus partly verified.

Two other factors may influence stygobite distribution in the studied area. Firstly, the major trend observed in the distribution of stygobite crustaceans in the studied sector was the significant difference in abundance and species richness between the assemblages sampled in the Ariège and the Hers groundwater systems. These differences are difficult to explain using the available set of environmental variables. Similar ranges for $\mathrm{pH}$ (an important factor for crustacean moult), dissolved oxygen (that can limit crustacean survival), and electrical conductivity (often linked to water origin and circulation patterns) were measured in the two alluvial plains in January 2012 when assemblages were sampled. Similarly, no obvious differences in land use characteristics could be found between the Ariège and Hers alluvial plain (Fig. 1A). Other biogeographical or hydrogeological variables must be considered to understand this between-plain heterogeneity, such as sediment characteristics and permeability, or nutrient availability. Secondly, the distance to the river influences the composition of stygobite assemblages. This influence was already reported in 1999 using 15 wells along the Ariège River (Dumas 2000, 2002). We found a similar influence of the distance to the river for the 16 wells located in the Ariège alluvial plain, where assemblage composition (i.e. the scores on the NMDS2 axis) was correlated to the distance to the river: $N$. kochianus decreased or disappeared in wells very close to the river. Such a distance may reflect the gradual river influence with buffered temporal variability at long distance (Dole \& Chessel, 1986). 
471 Thus, our results suggest that classical metrics of groundwater crustacean 472 assemblages, such as species composition, abundance and richness, may be of low 473 value for the evaluation of the impact of intensive agriculture on subterranean 474 ecosystems at the sector scale whereas better results may expected when wells are 475 considered individually. Contrasted results can be found in literature about the 476 relation between groundwater assemblages and land use. On one hand, Di Lorenzo 477 \& Galassi (2013) found stygobite species richness and abundance to be non478 sensitive to nitrate concentrations (up to $150 \mathrm{mg} / \mathrm{L}$ ) in the alluvial aquifer of the 479 Vibrata River in Italy, even if long-term effects could not be ruled out (Di Marzio et al., 480 2013). Similarly in Germany, Hahn (2006) and Griebler et al. (2010) found 481 inconsistent correlations between diversity and abundance of groundwater fauna and 482 physical and chemical variables. On the other hand, Di Lorenzo et al. (2015) 483 observed that groundwater assemblages sampled from bores in the alluvial plain of 484 the River Adige were sensitive to $\mathrm{NH}_{4}{ }^{+}$concentrations (here $\geq 0.032 \mathrm{mg} / \mathrm{L}$ ). It seems 485 that the effect of chronic toxicity of pollutants used in agriculture is more obvious 486 when considering the development rhythm of individuals instead of their mortality. 487 For example, Di Marzio et al (2013) observed that chronic exposure of interstitial 488 copepods to ammonium and herbicides (the carbamate pesticide Aldicarb) affected 489 the developmental time spent to reach the adult stage.

491 The community characteristics (i.e. composition, abundances, and species richness) 492 of stygobite crustaceans varied between wells according to the local context, but 493 were of poor value as ecological indicators at the sector scale compared to other 494 sites in Europe (Di Lorenzo et al., 2014) or North-Africa (Boulal et al., 1997). Future 495 research should include other groups of groundwater organisms in the assemblage 496 analyses, such as oligochaetes, molluscs, and bacteria. The microbes, and 497 especially bacteria, represent a considerable "hidden" biodiversity now quantifiable 498 with molecular techniques that may be used for groundwater ecosystem evaluation 499 (Griebler et al., 2010, 2014).

501 4.2. Relevance of sentinels in the evaluation of groundwater ecosystem health 502 Sentinel organisms caged in rivers and streams are now routinely used in the 503 bioassessment of surface water ecosystems (Maltby et al., 1990, 2002; Xuereb et al., 504 2009). The taxa used in situ for monitoring surface water include molluscs (Schmitt et 
al., 2010; Taleb et al., 2009), crustaceans (Coulaud et al., 2011; Debourge-Geffard et al., 2009; Maltby, 1995; Maltby \& Crane, 1994), insects (Custer et al., 2008) and fishes (Hanson, 2009). For groundwater ecosystems, Marmonier et al. (2013) proposed to distinguish the use of stygobionts, which may be resistant to long-term exposure (one month) and allow assessing diffuse pollution or providing a comprehensive evaluation of groundwater ecological quality, from the use of epigean species, which may resist to short-term exposure only (one week) allowing assessment of acute toxicity disturbances. Unfortunately, we did not find large numbers of stygobionts in the studied area (300 living individuals of the same species are necessary for 10 wells; Marmonier et al., 2013). So, we used a locally abundant epigean amphipod, Gammarus cf orinos living at the interface between groundwater and surface water (e.g. springs and small spring-fed streams). The use of an epigean taxon also limited the exposure duration to one week because of high physiological needs of surface water organisms (Hervant et al., 1998).

Several health criteria have been used to evaluate the degree of environmental disturbance resulting from exposure: (1) survival rate (Brown, 1980, Gust et al., 2010), (2) feeding activity (Coulaud et al., 2011; Crane et al., 1995; Forrow \& Maltby, 2000), (3) physiological parameters (e.g., respiration, Gerhardt, 1996; vitellogenesis, Xuereb et al., 2011) and (4) life-history traits (e.g., reproduction, Gust et al., 2011; Schmitt et al., 2010). In the present study, we used the EPI of Marmonier et al. (2013) that combines survival rates and changes in energetic stores expressed as a ratio between EPI measured in natura and obtained from reference individuals exposed in the laboratory (for comparisons between different periods of the year and different levels of energetic stores). Poor differences in the EPI score among cropbased sectors were observed during the period of low water transfer and low pollution (i.e. the dry season of a dry year), two months after the last potential pesticide application. In contrast, a strong upstream-downstream decreasing gradient in the EPI score occurred during the period of high water transfer and high pollution (i.e. a high water period of a wet year), during or just after a period of intensive agricultural activities (e.g. high and/or frequent pesticide applications). Chemical analyses of S-metolachlor confirmed these variable degrees of groundwater contamination between the two periods. This result suggests that sentinels caged in 
540 Agriculture-derived human activities weakly altered sentinel health, with an effect 541 only on energetic stores but not on survival rates. Similarly, Marmonier et al. (2013) 542 found an effect of urban stormwater infiltration on EPI scores (mainly due to inputs of 543 DOC and related decreases in dissolved oxygen concentration, Foulquier et al., 544 2010) but only weak effects on sentinel survival rates. Maazouzi et al. (2011) showed 545 that energetic stores, especially glycogen content, are valuable indicators of 546 environmental conditions for amphipods. The significant correlations of EPI with 547 dissolved oxygen (positive) and nitrate concentrations (negative) in the Ariège and 548 Hers alluvial plains during the high water transfer period suggest a link between sentinel health and agricultural practices.

As observed in earlier investigations in the studied sector (Amalric et al., 2013), Smetolachlor as well as its major metabolites (ethane sulfonic acid and oxalinic acid) were the predominant pesticides found in groundwater, followed by atrazine and two metabolites (deisopropylatrazine and deethylatrazine, noted DEA). S-metolachlor, one of the most commonly used herbicides in this area (Water Agency pers. comm.), is prone to leach into groundwater (Hladik et al., 2008; Baran \& Gourcy, 2013). Atrazine widely used for decades was withdrawn from agricultural practices in 2003. Nevertheless, atrazine and its major metabolite DEA have persisted in groundwater (Baran et al., 2007). When all pesticides were considered together, the significant correlation of EPI scores with PCA scores suggests that sentinel health can be negatively impacted by atrazine and two of its metabolites deisopropylatrazine, and desethylatrazine-DEA (Table 4). This herbicide is lowly to moderately toxic for crustaceans. The median effective concentration ( $E C_{50}$ for immobility after $48 \mathrm{~h}$ ) of Atrazine for Daphina magna is very high (35.5 $\pm 9.2 \mathrm{mg} / \mathrm{L}$, Palma et al., 2008) and reached $72 \mathrm{mg} / \mathrm{L}$ for the median lethal concentration $\left(L_{50}\right.$ after $48 \mathrm{~h}$, Wan et al., 2006). For the amphipod, the $\mathrm{LC}_{50}$ of Atrazine is $7.5 \mathrm{mg} / \mathrm{L}$ for Gammarus pulex (for 48h, Lukancic et al., 2010) and $10.1 \mathrm{mg} / \mathrm{L}$ for G. italicus (for 96h, Pantani et al., 1997). To our knowledge the toxicity of deisopropylatrazine for amphipods is not known, but we measure the acute toxicity of DEA for our sentinel species, $G$. cf orinos, that reached $10.1( \pm 1.1) \mathrm{mg} / \mathrm{L}\left(\mathrm{LC}_{50}\right.$ for $96 \mathrm{~h}$, Maazouzi et al., in prep.). In contrast, Atrazine concentrations in the groundwater of the studied sector ranged

572 from below the limit of quantification $(<L Q)$ to $0.205 \mu \mathrm{g} / \mathrm{L}$, deisopropylatrazine ranged 
573 from $<\mathrm{LQ}$ to $0.236 \mu \mathrm{g} / \mathrm{L}$ and $\mathrm{DEA}$ ranged from $<\mathrm{LQ}$ to $0.794 \mu \mathrm{g} / \mathrm{L}$. These values were

574 far below the toxicity limit of these compounds, at least for Atrazine and DEA.

575

576

The decrease in EPI in downstream wells surrounded by agriculture may result from the combination of several stressors, low values of dissolved oxygen, high nitrate concentrations or occurrence of pesticides being the most obvious, but other stressors not measured in our study (or peaks in herbicide applications not considered by our sampling strategy) may have contributed to the observed decrease in sentinel health. In the future, it would be essential to test the use of stygobite sentinels for longer exposure times (e.g. one month) that may integrate several episodes of pollution (e.g. Di Lorenzo et al., 2014). We also advocate repeated exposure experiments (i.e., at more than two periods) along a single year, to account for changes in agriculture activities and related groundwater quality. Finally, the EPI may be ameliorated and enriched with other potential ecophysiological indicators such as reproduction activities, development rates, or by proteomic analyses to determine the specific proteins indicative of particular stressors (Armengaud et al., 2014).

\section{Conclusion}

Three major conclusions arise from this study.

(1) The expected link between composition, abundance and diversity of stygobite assemblages and groundwater quality (reflecting agriculture intensity) was significant when wells were considered separately, but this relationship was highly variable. When sectors were compared, these global indicators were of poor value for the assessment of groundwater ecosystem health. Other variables must be included in future evaluation strategies, such as other biological groups (e.g. oligochaetes or microbes) or other biological characteristics (e.g. development rate, population structure).

(2) The sentinel experiment gave consistent results with a decrease in their ecophysiological status after one week of exposure in wells with low dissolved oxygen and high nitrate concentrations. We observed correlations between the EPI values measured on sentinels and occurrence of some organic molecules (e.g. 
606 atrazine and its metabolites, deisopropylatrazine and DEA) suggesting that sentinels were submitted to a combination of several stressors.

608 (3) This effect on sentinel health increased from the low- to the high-pollution transfer 609 periods. Longer exposure times and repeated exposure along the year may help for 610 a consistent evaluation of groundwater pollution in area of intensive agriculture and 611 more comprehensive sampling strategies for toxicants, such as Integrative Sampling 612 Techniques, are needed together with enriched ecophysiological indicators, such as 613 individual development rates or proteomic analyses.

\section{Acknowledgements}

616 This work, carried out within the framework of the ELISE project, was funded by the 617 Adour-Garonne Water Agency, the European Union (FEDER) and the BRGM (the 618 French Goelogical Survey). We thank the Long Term Ecological Research Zone 619 Atelier Bassin du Rhône (LTER ZABR) for fruitful interdisciplinary discussions over 620 the past three years. This work has been partly done by a research unit (USR 2936) 621 that is part of the "Laboratoire d'Excellence (LABEX)" entitled TULIP (ANR -10LABX-41).

\section{References}

Amalric, L., Baran, N., Coureau, C., Maingot, L., Buron, F., Routier, S., 2013. Analytical developments for 47 pesticides: first identification of neutral chloroacetanilide derivatives in French groundwater. International Journal Environmental Analytical Chemistry 93 (15), 1660-1675.

Armengaud, J., Trapp, J., Pible, O., Geffard, O., Chaumot, A., Hartmann, E.M., 2014. Non-model organisms, a species endangered by proteogenomics. Journal of Proteomics 105 (1), 5-18.

Baran, N., Mouvet, C., Négrel, P., 2007. Hydrodynamic and geochemical constraints on pesticide concentrations in the groundwater of an agricultural catchment (Brévilles, France). Environmental Pollution 148 (3), 729-738

Baran, N., Gourcy, L., 2013. Sorption and mineralization of S-metolachlor and its ionic metabolites in soils and vadose zone solids: consequences on groundwater quality in an alluvial aquifer (Plaine de l'Ain, France). Journal of Contaminant Hydrology 154, 20-28. 
640

641

642

643

644

645

646

647

648

649

650

651

652

653

654

655

656

657

658

659

660

661

662

663

664

665

666

667

668

669

670

671

672

673

Bohlke, J.K., 2002. Groundwater recharge and agricultural contamination. Hydrogeology Journal 10 (1), 153-179.

Bou, C., Rouch, R., 1967. Un nouveau champ de recherches sur la faune aquatique souterraine. Compte-Rendu de l'Académie des Sciences, Biologie 265 (4), 369370.

Boulal, M., Touyer, A., Boutin, C., 1997. Qualité de l'eau et faune aquatique des puits près d'Agadir, dans le secteur aval de la plaine du Souss (Maroc). Bulletin de la Société d'Histoire Naturelle de Toulouse 133, 59-70.

Boulton, A.J., 2005. Chances and challenges in the conservation of groundwaters and their dependant ecosystems. Aquatic Conservation: Marine and Freshwater Ecosystems 15 (4), 319-323.

Boulton, A.J., 2009. Recent progress in the conservation of groundwater and their dependent ecosystems. Aquatic Conservation: Marine and Freshwater Ecosystems 19 (7), 731-735.

Brown, L., 1980. The use of Hydrobia jenkensi to detect intermittent toxic discharges to a river. Water Research 14 (8), 941-947.

Burke, J.J., 2003. Groundwater for irrigation: productivity gains and the need to manage hydro-environmental risk. In: Llamas R. \& Custodio E. (Eds), Intensive use of groundwater, challenges and opportunities. Swets \& Zeitlinger Publ., Lisse, The Netherland, p. 59-91.

Coulaud, R., Geffard, O., Xuereb, B., Lacaze, E., Quéau, H., Garric, J., Charles, S., Chaumot, A., 2011. In situ feeding assay with Gammarus fossarum (Crustacea): modelling the influence of confounding factors to improve water quality biomonitoring. Water Research 45 (19), 6417-6429.

Crane, M., Delaney, P., Mainstone, C. and Clarke, S., 1995. Measurement by in situ bioassay of water quality in an agricultural catchment. Water Research 29 (11), 2441-2448.

Custer K.W., Burton G.A., 2008. Isonychia spp. and macroinvertebrate community responses to stressors in streams utilizing the benthic in situ toxicity identification evaluation (BiTIE) method. Environmental Pollution, 151 (1): 101-109.

Danielopol, D.L., 1989. Groundwater fauna associated with riverine aquifers. Journal of the North American Benthological Society 8 (1), 18-35.

Danielopol, D.L., Drozdowski, G., Mindl, B., Neudorfer, W., Pospisil, P., Reiff, N., Schabetsberger, R., Stichler, W., Griebler, C., 2006a. Invertebrate animals and 
microbial assemblages as useful indicators for evaluation of the sustainability and optimization of an artificial groundwater-recharge system (Stallingerfeld, Deutsch-Wagram, Lower Austria), In: Kovar, K., Hrkal, Z., Bruthans, J. (Eds.), International Conference on Hydrology and Ecology: the groundwater-ecology connection, p149-156. Proceedings, Czech Assoc. Hydrogeologists, Special Publication, Prague, p.149-156.

Danielopol, D.L., Gibert, J., Griebler, C., 2006b. Efforts of the European Commission to improve communication between environmental scientists and policy-makers. Environmental Science and Pollution Research 13 (2), 138-139.

Danielopol, D.L., Gibert, J., Griebler, C., Gunatilaka, A., Hahn, H.J., Messana, G., Notenboom, J., Sket, B., 2004. Incorporating ecological perspectives in European groundwater management policy. Environmental Conservation 31 (3), $1-5$.

Danielopol, D.L., Griebler, C., Gunatilaka, A., Hahn, H.J., Gibert, J., MermillodBlondin, F., Messana, G., Notenboom, J., Sket B., 2008. Incorporation of groundwater ecology in environmental policy, In: Quevauviler, P. (Ed.), Groundwater Science and Policy - An international overview. RSC Publishing. The Royal Society of Chemistry, London, p. 671-689.

Datry, T., Malard, F., Gibert J., 2005. Response of invertebrate assemblages to increased groundwater recharge rates in a phreatic aquifer. Journal of the North American Benthological Society 24 (3), 461-477.

Datry, T., Malard, F., Gibert, J., 2004. Dynamics of solutes and dissolved oxygen in shallow urban groundwater infiltration basin. Science of the Total Environment 329 (1-3), 215-229.

Debourge-Geffard, O., Palais, F., Biagianti-Risbourg, S., Geffard, O., Geffard, A., 2009. Effects of metal on feeding rate and digestive enzymes in Gammarus fossarum: an in situ experiment. Chemosphere 77 (11), 1569-1576.

Di Lorenzo, T., Brilli, M., Del Tosto, D., Galassi, D.M.P., Petitta M., 2012. Nitrate source and fate at the catchment scale of the Vibrata River and aquifer (central Italy): an analysis by integrating component approaches and nitrogen isotopes. Environmental Earth Sciences 67 (8), 2383-2398.

Di Lorenzo, T., Galassi, D.M.P., 2013. Agricultural impacts on Mediterranean alluvial aquifers: do invertebrates respond? Fundamental and Applied Limnology 182 (4), 271-281. 
Di Lorenzo, T., Cifoni, M., Lombardo, P., Fiasca, B., Galassi, D.M.P., 2015. Threshold value for groundwater quality in the EU may not protect groundwater fauna: evidence from an alluvial aquifer in Italy. Hydrobiologia, 743 (1),139 - 150.

Di Lorenzo, T., Di Marzio, W.D., Sáenz, M.E., Baratti, M. Dedonno, A.A., lannucci, A., Cannicci, S., Messana, G., Galassi, D.M.P., 2014. Sensitivity of hypogean and epigean freshwater copepods to agricultural pollutants. Environmental Science and Pollution Research 21 (6), 4643-4655.

Di Marzio, W.D., Castaldo, D., Di Lorenzo, T., Di Cioccio, A., Sáenz, M.E., Galassi, D.M.P., 2013. Developmental endpoints of chronic exposure to suspected endocrine-disrupting chemicals (EDCs) on benthic and hyporheic freshwater copepods. Ecotoxicology and Environmental Safety 96 (1), 86-92.

Dole, M.-J., Chessel, D., 1986. Stabilité physique et biologique des milieux interstitiels. Cas de deux stations du Haut-Rhône. Annales de Limnologie 22 (1), 69-81.

Dole, M.-J., Mathieu, J., 1984. Etude de la "pellicule biologique" dans des milieux interstitiels de l'Est Lyonnais. Verhandlungen des Internationalen Verein Limnologie 22, 1745-1750.

Dumas, P., 2000. Les Crustacés souterrains, indicateurs naturels de l'aquifère alluvial de l'Ariege (France, Pyrénées). PhD thesis University Toulouse III, 163 p.

Dumas, P., 2002. Stability of interstitial crustacean community in an isolated alluvial aquifer. Hydrobiologia, 468 (1), 63-76.

European Environmental Agency, 2010. The European Environment. State and outlook 2010. Freshwater quality. Publications Office of the European Union, Luxembourg. doi: 10.2800/60214.

European Commission, 2000. Directive 2000/60/EC of the European Parliament and the Council of the 23 October 2000 establishing a framework for community action in the field of water policy. Official Journal of the European Commission L327, 1-73.

European Commission, 2006. Directive 2006/118 of the European Parliament and the Council of the 12 December 2006. Official Journal of the European Commission L372, 19-31.

Fiasca, B., Stoch, F., Olivier, M.-J., Maazouzi,C., Petitta, M., Di Cioccio, A., Galassi, D.M.P., 2014. The dark side of springs: what drives small-scale spatial patterns of subsurface meiofaunal assemblages? Journal of Limnology 73 (1), 55-64. 
Fiser, C., Sket, B. and Trontelj, P. 2008. A phylogenetic perspective on 160 years of troubled taxonomy of Niphargus (Crustacea: Amphipoda). Zoologica Scripta 37 (6), 665-680.

Forrow, D. M., Maltby, L., 2000. Toward a mechanistic understanding of contaminant-induced changes in detritus processing in streams: Direct and indirect effects on detritivore feeding. Environmental Toxicology and Chemistry 19 (8), 2100-2106.

Foulquier, A., Malard, F., Mermillod-Blondin, F., Datry, T., Simon, L., Montuelle, B., Gibert, J., 2010. Vertical change in dissolved organic carbon and oxygen at the water table region of an aquifer recharged with stormwater: biological uptake or mixing? Biogeochemistry 99 (1-3), 31-47.

Foulquier, A., Mermillod-Blondin, F., Malard, F., J. Gibert, 2011. Response of sediment biofilm to increased dissolved organic carbon supply in groundwater artificially recharged with stormwater. Journal of Soils and Sediments 11 (2), 382393.

Gerhardt, A., 1996. Behavioural early warning responses to polluted water Performance of Gammarus pulex L. (Crustacea) and Hydropsyche angustipennis (Curtis) (Insecta) to a complex industrial effluent. Environmental Science and Pollution Research 3 (2), 63-70.

Griebler, C., Malard, F., Lefebure, T., 2014. Current developments in groundwater ecology - from biodiversity to ecosystem function and services. Current Opinion in Biotechnology 27, 159-167.

Griebler, C., Stein, H., Kellermann, C., Berkhoff, S., Brielmann, H., Schmidt, S., Selesi, D., Steube, C., Fuchs, A., Hahn, H.J., 2010. Ecological assessment of groundwater ecosystems - Vision or illusion? Ecological Engineering 36 (9), 1174-1190.

Gust, M., Buronfosse, T., Geffard, O., Coquery, M., Mons, R., Abbaci, K., Giamberini, L., Garric, J., 2011. Comprehensive biological effects of a complex field polymetallic pollution gradient on the New Zealand mudsnail Potamopyrgus antipodarum (Gray). Aquatic Toxicology 101 (1), 100-108.

Gust, M., Buronfosse, T., Geffard, O., Mons, R., Queau, H., Mouthon, J., Garric, J., 2010. In situ biomonitoring of freshwater quality using the New Zealand mudsnail Potamopyrgus antipodarum (Gray) exposed to waste water treatment plant (WWTP) effluent discharges. Water Research 44 (15), 4517-4528. 
Gutjahr, S., Bork, J., Hahn, H.J., 2013. Grundwasserfauna als Indikator für komplexe hydrogoelogische Verhältnisse am westlichen Kaiserstuhl. Grundwasser 18 (3), 173-184.

Hahn, H.J., 2006. The GW-Fauna-Index: a first approach to a quantitative ecological assessment of groundwater habitats. Limnologica 36 (2), 119-137.

Hall, T.A., 1999. BioEdit: a user-friendly biological sequence alignment editor and analysis program for Windows 95/98/NT. Nucleic Acids Symposium Series 41, 95-98.

Hancock, P.J., Boulton, A.J., Humphreys, W.F., 2005. Aquifer and hyporheic zones: towards an ecological understanding of groundwater. Hydrogeology Journal 13 (1), 98-111.

Hanson, N., 2009. Utility of biomarkers in fish for environmental monitoring. Integrated Environmental Assessment and Management 5 (1), 180-181.

Hervant, F., Mathieu, J., Messana, B., 1998. Oxygen consumption and ventilation in declining oxygen tension and posthypoxic recovery in epigean and hypogean crustaceans. Journal of Crustacean Biology 18 (4), 717-727.

Hervant, F., Mathieu, J., Garin, D., Freminet, A., 1995. Behavioural, ventillatory, and metabolic responses to severe hypoxia and subsequent recovery of the hypogean Niphargus rhenorhodanensis and the epigean Gammarus fossarum (Crustacea: Amphipoda). Physiological Zoology 68 (2), 223-244.

Hervant, F., Mathieu, J., Garin, D., Fréminet, A., 1996. Behavioral, ventilatory and metabolic responses of the hypogean amphipod Niphargus virei and the epigean isopod Asellus aquaticus to severe hypoxia and subsequent recovery. Physiological Zoology 69 (6), 1277-1300.

Hladik, M.L., Bouwer, E.J., Roberts, A.L., 2008. Neutral chloroacetamide herbicide degradates and related compounds in Midwestern United States drinking water sources. Science of the Total Environment 390 (1), 155-165.

Janiaud, N., 2004. Evaluation de la sensibilité des crustacés aquatiques des nappes alluviales aux micropolluants organiques et minéraux - Test sur la nappe alluviale de l'Ariège. Adour-Garonne Water Agency (Ed.), Toulouse, France. 135 p.

Korbel, K.L., Hose, G.C., 2011. A tiered framework for assessing groundwater ecosystem health. Hydrobiologia 661 (1), 329-349. 
809

810

811

812

813

814

815

816

817

818

819

820

821

822

823

824

825

826

827

828

829

830

831

832

833

834

835

836

837

838

839

840

841

842

Lapworth, D.J., Baran, N., Stuart, M.E, Ward, R.S., 2012. Emerging organic contaminants in groundwater: A review of sources, fate and occurrence. Environmental Pollution 163, 287-303.

Legendre, P., Legendre, L, 1998. Numerical Ecology. Elsevier, Amsterdam, The Netherland. $1006 \mathrm{p}$.

Legout, C., Molenat, J., Aquilina, L., Gascuel-Odoux, C., Faucheux, M., Fauvel, Y., Bariac, T., 2007. Solute transfer in the unsaturated zone-groundwater continuum of a headwater catchment. Journal of Hydrology 332 (3-4), 427-441.

Legout, C., Molenat, J., Lefebvre, S., Marmonier, P., Aquilina, L., 2005. Investigation of biogeochemical activities in the soil and unsaturated zone of weathered granite. Biogeochemistry 75 (2), 329-350.

Lerner, D.N., Barrett, M.H., 1996. Urban groundwater issues in the United Kingdom. Hydrogeology Journal 4 (4), 80-89.

Lukancic S., Zibrat U., Mezek T. Jerebic A., Simcic T., Brancelj A., 2010. Effect of exposing two non-target crustacean species, Asellus aquaticus L., and Gammarus pulex Koch., to Atrazine and Imidacloprid. Bulletin of Environmental Contamination Toxicology 84 (1), 85-90.

Maazouzi, C., Piscart, C., Legier, F., Hervant, F., 2011. Ecophysiological responses to temperature of the "killer shrimp" Dikerogammarus villosus: Is the invader really stronger than the native Gammarus pulex? Comparative Biochemistry and Physiology - Part A Physiology 59 (3), 268-274.

Malard, F., Ferreira, D., Doledec, S., and Ward, J. V., 2003. Influence of groundwater upwelling on the distribution of the hyporheos in a headwater river flood plain. Archive für Hydrobiologie 157 (1), 89-116.

Malard, F., Tockner, K., Dole-Olivier, M.-J., and Ward, J. V., 2002. A landscape perspective of surface-subsurface hydrological exchanges in river corridors. Freshwater Biology 47 (4), 621-640.

Maltby, L., 1995. Sensitivity of the crustaceans Gammarus pulex (L.) and Asellus aquaticus (L.) to short-term exposure to hypoxia and unionized ammonia: observation and possible mechanisms. Water Research 29 (3), 781-187.

Maltby, L., Clayton, S. A., Wood, R. M., McLoughlin, N., 2002. Evaluation of the Gammarus pulex in situ feeding assay as a biomonitor of water quality: Robustness, responsiveness, and relevance. Environmental Toxicology and Chemistry 21 (2), 361-368. 
Maltby, L., Crane, M., 1994. Responses of Gammarus pulex (Amphipoda, Crustacea) to metallic effluents: identification of toxic components and the importance of interpopulation variation. Environmental Pollution 84 (1), 45-52.

Maltby, L., Naylor, C., Calow, P., 1990. Field deployment of a scope for growth assay involving Gammarus pulex, a freshwater benthic invertebrate. Ecotoxicology and Environmental Safety 19 (3), 292-300.

Marmonier, P., Maazouzi, C., Foulquier, A., Navel, S., François, C., Hervant, F., Mermillod-Blondin, F., Vieney, A., Barraud, S., Togola, A., \& Piscart, C., 2013. The use of crustaceans as sentinel organisms to evaluate groundwater ecological quality. Ecological Engineering 57, 118-132.

Marmonier, P., Vervier, P., Gibert, J. \& Dole-Olivier, M.J. 1993. Biodiversity in ground waters. Trends in Ecology and Evolution 8 (11), 392-395.

Martin, C., Molenat, J., Gascuel-Odoux, C., Vouillamoz, J.M., Robain, H., Ruiz, L., Faucheux, M., Aquilina, L., 2006. Modeling the effect of physical and chemical characteristics of shallow aquifers on water and nitrate transport in small agricultural catchments. Journal of Hydrology 326 (1-4), 25-42.

Mermillod-Blondin, F., Foulquier, A., Maazouzi, C., Navel, S., Negrutiu, Y., Vienney, A., Simon, L., Marmonier, P., 2013. Ecological assessment of groundwater trophic status by using artificial substrates to monitor biofilm growth and activity. Ecological Indicators 25, 230-238.

Mösslacher, F., 2000. Advantages and disadvantages of groundwater organisms for biomonitoring. Verhandlungen des Internationalen Verein Limnologie 27, 27252728.

Nogaro, G., Mermillod-Blondin, F., Montuelle, B., Boisson, J.C., Gibert, J., 2008. Chironomid larvae stimulate biogeochemical and microbial processes in a riverbed covered with fine sediment. Aquatic Science 70 (2), 156-168.

Oksanen, J., Blanchet, G.F., Kindt, R., Legendre, P., Minchin, P.R., O'Hara, R. B., Simpson, G. L., Solymos, P., Stevens, M. H. H., Wagner, H., 2012. Vegan: Community Ecology Package. $R$ package version 2.0-5. Available at: http://CRAN.R-project.org/package=vegan.

Palma, P., Palma, V.L., Fernandes, R.M., Soares, A.M.V.M., Barbosa, I.R., 2008. Acute toxicity of Atrazine, Endosulfan Sulphate and Chloropyrifos to Vibrio ficheri, Thamnocephalus platyurus and Daphnia magna, relative to their concentrations 
in surface waters from the Alentejo region of Portugal. Bulletin of Environmental Contamination Toxicology 81 (5), 485-489.

Pantani, C., Pannunzio, G., De Cristfaro, M., Novelli, A.A., Slavatori, M., 1997. Comparative acute toxicity of some pesticides, metals and surfactants to Gammarus italicus Goedm. and Echinogammarus tibaldii Pink. and Stock (Crustacea: Amphipoda). Bulletin of Environmental Contamination Toxicology 59 (6), 963-967.

Quinn, G.P., Keough, M.J., 2002. Experimental Design and Data Analysis for Biologists. Cambridge University Press, Cambridge, UK, 557 p.

R Development Core Team, 2013. R: A language and environment for statistical computing. - R Foundation for Statistical Computing, Vienna, Austria. Available at: http://www.R-project.org.

Ramsar Convention Secretariat, 2010. Managing groundwater: guidelines for the management of groundwater to maintain wetland ecological characters. Ramsar handbooks for the wise use of wetlands, $4^{\text {th }}$ edition, vol. 11, Gland, Swiss, $48 \mathrm{p}$.

Schmitt, C., Vogt, C., Ballaer, B., Brix, R., Suetens, A., Schmitt-Jansen, M., de Deckere, E., 2010. In situ cage experiment with Potamopyrgus antipodarum - A novel tool for real life exposure assessment in freshwater ecosystems. Ecotoxicology and Environmental Safety 73 (7), 1574-1579

Stein, H., Kellermann, C., Schmidt, S.I., Brielmann, H., Steube, C., Berkhoff, S.E., Fuchs, A. Hahn, H.J., Thulin, B., Griebler, C., 2010. The potential use of fauna and bacteria as ecological indicators for the assessment of groundwater ecosystems. Journal of Environmental Monitoring 12 (1), 242-254.

Steube, C., Richter, S., Griebler, C., 2009. First attempts towards an integrative concept for the ecological assessment of groundwater ecosystems. Hydrogeology Journal 17 (1), 23-35.

Taleb, Z., Benali, I., Gherras, H., Yklef-Alla,I A., Bachir-Bouiadjra, B., Amiard, J.C., Boutiba, Z., 2009. Biomonitoring of environmental pollution on the Algerian west coast using caged mussels Mytilus galloprovincialis. Oceanologia 51 (1), 63-84.

Tamura, K., Peterson, D., Peterson, N., Stecher, G., Nei, M., Kumar, S., 2011. MEGA5: Molecular Evolutionary Genetics Analysis Using Maximum Likelihood, Evolutionary Distance, and Maximum Parsimony. Methods in Molecular Biology and Evolution 28 (10), 2731-2739. 
Tomlinson, M., Boulton, A.J., Hancock, P.J., Cook, P.G., 2007. Deliberate omission or unfortunate oversight: should stygofaunal survey be included in routine groundwater monitoring programs? Hydrogeology Journal 15 (7), 1317-1320.

Trauth, R., Xanthopoulos, C., 1997. Non-point pollution of groundwater in urban areas. Water Research 31 (11), 2711-2718.

Van der Gun, J., 2012. Groundwater and global change: trends, opportunities and challenges. UNESCO, Paris, France, $44 \mathrm{p}$.

Wan, M.T., Buday, C., Schroeder, G., Kuo, J., Pasternak, J., 2006. Toxicity to Daphnia magna, Hyalella Azteca, Oncorhynchus kisutch, Oncorhynchus mykiss, Oncorhynchus tshawytscha, and Rana catesbeiana of Atrazine, Metolachlor, Simazine, and their formulated products. Bulletin of Environmental Contamination and Toxicology 76 (1), 52-58.

Williamson, W.M., Close, M.E., Leonard, M.M., Webber, J.B., Lin, S., 2012. Groundwater biofilm dynamics grown in situ along a nutrient gradient. Groundwater 50 (5), 690-703.

Xuereb, B., Bezin, L., Chaumot, A., Budzinski, H., Augagneur, S., Tutundjian, R., Garric, J., Geffard, O., 2011. Vitellogenin-like gene expression in freshwater amphipod Gammarus fossarum (Koch, 1835): functional characterization in females and potential for use as an endocrine disruption biomarker in males. Ecotoxicology 20 (6), 1286-1299.

Xuereb, B., Chaumot, A., Mons, R., Garric, J., Geffard, O., 2009. Acetylcholinesterase activity in Gammarus fossarum (Crustacea Amphipoda). Intrinsic variability, reference levels, and a reliable tool for field surveys. Aquatic Toxicology 93 (4), 225-233.

Zar, J.H., 2009. Biostatistical Analysis, 5th edition. Prentice Hall / Pearson, Upper Saddle River, NJ, USA, $944 \mathrm{p}$.

Zektser, I.S., Everett, L.G., 2004. Groundwater resources of the world and their use. Series on Groundwater, UNESCO, Paris, France, 342 p. 
940 Table 1: Physical and chemical characteristics of the groundwater sampled during the 941 invertebrate survey of January 2012 in 28 wells located in the six sectors of the Ariège and 942 Hers alluvial plains. Sectors are upstream (HUp) and downstream (HDw) of the Hers plain, 943 upstream (AUp), intermediate (Alnt1 and Alnt2) and downstream (ADw) of the Ariège plain ( $n$ $944=$ number of wells sampled in each sector). Parameters include temperature (Temps. in ${ }^{\circ} \mathrm{C}$ ), 945 electric conductivity ( $\mathrm{EC}$ in $\mu \mathrm{S} / \mathrm{cm}$ ), $\mathrm{pH}$, oxygen concentrations (Oxy. in $\mathrm{mg} / \mathrm{L}$ ), and nitrate 946 concentrations $\left(\mathrm{NO}_{3}\right.$ in $\mathrm{mg} / \mathrm{L}$; mean \pm standard deviation). The land-cover around the 28 947 wells was used to characterize the six sectors with forest, grassland, urban area, total 948 cultivated area (mainly corn) and oleaginous seed production (mainly sunflower, mean 949 percentages \pm standard deviation using wells as replicates). 950

\begin{tabular}{lcccccc} 
& $\begin{array}{c}\mathrm{HUp} \\
(\mathrm{n}=6)\end{array}$ & $\begin{array}{c}\mathrm{HDw} \\
(\mathrm{n}=6)\end{array}$ & $\begin{array}{c}\text { AUp } \\
(\mathrm{n}=4)\end{array}$ & $\begin{array}{c}\text { Alnt1 } \\
(\mathrm{n}=4)\end{array}$ & $\begin{array}{c}\text { Alnt2 } \\
(\mathrm{n}=4)\end{array}$ & $\begin{array}{c}\text { ADw } \\
(\mathrm{n}=4)\end{array}$ \\
\hline Temp. & $12.6 \pm 1.5$ & $12.3 \pm 0.9$ & $12.9 \pm 1.8$ & $10.9 \pm 1.3$ & $11.4 \pm 1.9$ & $11.9 \pm 1.8$ \\
$\mathrm{EC}$ & $640 \pm 95$ & $571 \pm 193$ & $413 \pm 228$ & $502 \pm 50$ & $730 \pm 57$ & $879 \pm 228$ \\
$\mathrm{pH}$ & $7.2 \pm 0.1$ & $7 \pm 0.3$ & $7 \pm 0.1$ & $6.9 \pm 0.1$ & $7.2 \pm 0.2$ & $7.3 \pm 0.1$ \\
Oxy. & $5.0 \pm 1.4$ & $4.8 \pm 2.9$ & $7.3 \pm 1.8$ & $5.3 \pm 1.1$ & $5.4 \pm 1.4$ & $3.7 \pm 1.4$ \\
$\mathrm{NO}_{3}{ }^{*}$ & $34.9 \pm 11.6$ & $96.31 \pm 36.6$ & $28.6 \pm 13.4$ & $63.7 \pm 21.4$ & $87.3 \pm 30.3$ & $54.9 \pm 14.2$ \\
& & & & & & \\
Forest & $6 \pm 5.9$ & $1.5 \pm 0.8$ & $7.7 \pm 11.3$ & $2.5 \pm 2.6$ & $2.4 \pm 2.4$ & $1.4 \pm 1.0$ \\
Grassland & $21.2 \pm 10.3$ & $11.7 \pm 5.9$ & $24.8 \pm 11.3$ & $15.8 \pm 4.3$ & $12.3 \pm 3.5$ & $7.9 \pm 5.4$ \\
Urban & $3.4 \pm 2.7$ & $10.3 \pm 7.2$ & $20 \pm 11.5$ & $7.4 \pm 4$ & $28.8 \pm 19.9$ & $37.9 \pm 21.7$ \\
Cultivated & $48.6 \pm 30.2$ & $76.2 \pm 9.2$ & $38 \pm 20.2$ & $73.7 \pm 7.3$ & $49.1 \pm 19.9$ & $42.8 \pm 14.8$ \\
Oleaginous & $14.1 \pm 11.1$ & $43.3 \pm 20.2$ & $11.8 \pm 7$ & $43.9 \pm 15.3$ & $17.2 \pm 11.7$ & $7.9 \pm 8.5$ \\
\hline
\end{tabular}

*Mean values (and SD) for nitrate were calculated on the basis of the monthly 2012-13 water 953 survey (BRGM, in prep). 
955 Table 2: Abundances (mean number of individuals per sample \pm standard deviation) of 956 stygobite species collected in the wells of the Ariège and Hers alluvial plains. Sectors are 957 upstream (HUp) and downstream (HDw) of the Hers, upstream (AUp), intermediate (Alnt1 958 and Alnt2) and downstream (ADw) of the Ariège ( $n=$ number of wells sampled in each 959 sector).

960

\begin{tabular}{|c|c|c|c|c|c|c|c|}
\hline Groups & Species & $\begin{array}{l}\text { HUp } \\
(n=6)\end{array}$ & $\begin{array}{l}\mathrm{HDw} \\
(\mathrm{n}=6)\end{array}$ & $\begin{array}{l}\text { AUp } \\
(n=4)\end{array}$ & $\begin{array}{l}\text { Alnt1 } \\
(n=4)\end{array}$ & $\begin{array}{l}\text { Alnt2 } \\
(n=4)\end{array}$ & $\begin{array}{l}\text { ADw } \\
(n=4)\end{array}$ \\
\hline \multirow[t]{6}{*}{ Amphipods } & Niphargus kochianus & $\begin{array}{r}9.5 \\
\pm 12.7\end{array}$ & $\begin{array}{r}16.2 \\
\pm 18.5\end{array}$ & $\begin{array}{r}7.3 \\
\pm 12\end{array}$ & $\begin{array}{c}6.5 \\
\pm 12.3\end{array}$ & $\begin{array}{r}2.5 \\
\pm 3.8\end{array}$ & $\begin{array}{r}0.5 \\
\pm 0.6\end{array}$ \\
\hline & Niphargus ciliatus & $\begin{array}{c}1 \\
\pm 2\end{array}$ & $\begin{array}{l}3 \\
\pm 3.9\end{array}$ & 0 & $\begin{array}{l}0.3 \\
\pm 0.5\end{array}$ & 0 & $\begin{array}{l}0.5 \\
\pm 1\end{array}$ \\
\hline & Niphargus foreli & $\begin{array}{c}2.2 \\
\pm 5.3\end{array}$ & $\begin{array}{r}2.5 \\
\pm 6.1\end{array}$ & 0 & 0 & 0 & 0 \\
\hline & Niphargus sp. & $\begin{array}{c}0.3 \\
\pm 0.8\end{array}$ & 0 & 0 & 0 & 0 & 0 \\
\hline & Salentinella major & $\begin{array}{l}5.7 \\
\pm 7\end{array}$ & 0 & 0 & $\begin{array}{l}2 \\
\pm 3.4\end{array}$ & $\begin{aligned} & 4 \\
\pm & 4.7\end{aligned}$ & 0 \\
\hline & Salentinella petiti & $\begin{array}{r}2.7 \\
\pm 4.4 \\
\end{array}$ & 0 & 0 & $\begin{array}{c}2 \\
\pm 4 \\
\end{array}$ & $\begin{array}{r}2.7 \\
\pm 2.4 \\
\end{array}$ & 0 \\
\hline \multirow[t]{4}{*}{ Copepods } & Ceuthonectes gallicus & 0 & 0 & 0 & 0 & $\begin{array}{l}0.5 \\
\pm 1\end{array}$ & 0 \\
\hline & Diacyclops paolae & $\begin{array}{c}0.2 \\
\pm 0.4\end{array}$ & 0 & 0 & 0 & $\begin{array}{l}1.5 \\
\pm 3\end{array}$ & 0 \\
\hline & Diacyclops clandestinus & 0 & $\begin{array}{c}0.2 \\
\pm 0.4\end{array}$ & 0 & 0 & 0 & 0 \\
\hline & Diacyclops belgicus & $\begin{array}{r}13 \\
\pm \\
+31.8 \\
\end{array}$ & 0 & 0 & 0 & 0 & 0 \\
\hline \multirow[t]{4}{*}{ Ostracods } & Candonopsis boui & $\begin{array}{c}3.8 \\
\pm 6.1\end{array}$ & 0 & 0 & 0 & 0 & 0 \\
\hline & Pseudocandona sp. 1 & 0 & 0 & 0 & 0 & $\begin{array}{r}5.5 \\
\pm 11\end{array}$ & 0 \\
\hline & Pseudocandona sp. 2 & $\begin{array}{c}4.3 \\
\pm 10.6\end{array}$ & 0 & 0 & 0 & 0 & 0 \\
\hline & Pseudocandona sp. 3 & 0 & $\begin{array}{l}26 \\
\pm 56.7 \\
\end{array}$ & 0 & 0 & 0 & 0 \\
\hline Abundances & & $\begin{array}{c}43.7 \\
\pm 32.3\end{array}$ & $\begin{array}{c}52.5 \\
\pm 49.9\end{array}$ & $\begin{array}{r}7.5 \\
\pm 11.9\end{array}$ & $\begin{array}{r}11.3 \\
\pm 12.2\end{array}$ & $\begin{array}{r}18.8 \\
\pm 15.0\end{array}$ & $\begin{array}{r}1.3 \\
\pm 1.9\end{array}$ \\
\hline Richness & & $\begin{array}{c}8.2 \\
\pm 3.9 \\
\end{array}$ & $\begin{array}{r}6.5 \\
\pm 1.0 \\
\end{array}$ & $\begin{array}{r}2.5 \\
\pm 2.4 \\
\end{array}$ & $\begin{array}{r}4.8 \\
\pm 2.9 \\
\end{array}$ & $\begin{array}{c}6.0 \\
\pm 1.4 \\
\end{array}$ & $\begin{array}{r}3.8 \\
\pm 2.1 \\
\end{array}$ \\
\hline
\end{tabular}

961

962 
964 Table 3. Scores of land use and physical and chemical characteristics along the first 965 (NMDS1) and second (NMDS2) axes. Goodness-of-fit statistics between variables 966 and NMDS ordination is given by a squared correlation coefficient $\left(r^{2}\right)$ and the 967 significance of the fit is given by a $\mathrm{P}$-value (noted with * when $\mathrm{P}<0.05$ ).

968

969

970

971

972

973

974

975

976

977

978

$\begin{array}{lcccl} & \text { NMDS1 } & \text { NMDS2 } & r^{2} & \text { P-value } \\ \text { Urban } & -0.0436 & -0.9990 & 0.005 & 0.949 \\ \text { Forest } & 0.3563 & -0.9344 & 0.134 & 0.248 \\ \text { Grassland } & 0.7362 & 0.6767 & 0.285 & \mathbf{0 . 0 4 6} \text { * } \\ \text { Cultivated } & -0.9758 & 0.2186 & 0.343 & \mathbf{0 . 0 2 2} \text { * } \\ \text { Oxygen } & 0.5587 & 0.8294 & 0.105 & 0.362 \\ \text { Temperature } & 0.0052 & -0.9999 & 0.019 & 0.840 \\ \text { Conductivity } & 0.1056 & -0.9944 & 0.088 & 0.408 \\ \text { pH } & 0.7987 & 0.6018 & 0.159 & 0.203\end{array}$

979

980

981

982

983 
Table 4: First-five axes of a PCA performed on chemical and toxicant parameters. Data below represent correlations between each PCA axis and each input variable. The percentage of variance explained by each axis is indicated under brackets. Bolded values indicate the most important variables loading along each axis using an arbitrary threshold of 0.5 .

\begin{tabular}{llllll}
\hline Variables & \multicolumn{1}{c}{$\begin{array}{c}\text { Axis 1 } \\
(30.11 \%)\end{array}$} & $\begin{array}{c}\text { Axis 2 } \\
(21.14 \%)\end{array}$ & $\begin{array}{c}\text { Axis 3 } \\
(13.70 \%)\end{array}$ & $\begin{array}{c}\text { Axis 4 } \\
(10.08 \%)\end{array}$ & $\begin{array}{c}\text { Axis 5 } \\
(7.63 \%)\end{array}$ \\
\hline Atrazine & $\mathbf{0 . 8 7 9}$ & -0.118 & 0.157 & 0.245 & -0.018 \\
Desethylatrazine & $\mathbf{0 . 9 3 4}$ & 0.016 & -0.003 & 0.097 & 0.053 \\
Deisopropylatrazine & $\mathbf{0 . 9 6 0}$ & -0.056 & 0.015 & 0.098 & 0.115 \\
Metolachlor & -0.144 & $\mathbf{0 . 7 3 8}$ & 0.568 & -0.258 & -0.098 \\
Simazine & 0.762 & -0.205 & 0.066 & 0.207 & -0.179 \\
OXA Metolachlor & -0.162 & $\mathbf{0 . 7 3 9}$ & $\mathbf{0 . 5 7 3}$ & -0.270 & -0.113 \\
ESA Metolachlor & $\mathbf{0 . 5 2 5}$ & 0.365 & $\mathbf{0 . 5 8 7}$ & -0.419 & -0.042 \\
Acetochlor Ethane sulfonic & -0.242 & 0.147 & -0.227 & -0.053 & $\mathbf{0 . 7 6 3}$ \\
Alachlor Ethane sulfonic & $\mathbf{0 . 5 7 4}$ & 0.219 & -0.077 & 0.308 & 0.327 \\
Conductivity & -0.024 & $\mathbf{0 . 8 4 3}$ & -0.212 & 0.440 & -0.022 \\
pH & $-\mathbf{0 . 5 1 2}$ & 0.321 & 0.289 & $\mathbf{0 . 5 2 4}$ & 0.105 \\
Water temperature & 0.099 & -0.008 & $-\mathbf{0 . 7 0 6}$ & -0.327 & -0.506 \\
Dissolved oxygen & $-\mathbf{0 . 5 5 3}$ & $\mathbf{- 0 . 5 0 1}$ & 0.198 & 0.384 & 0.088 \\
Eh & 0.205 & $\mathbf{- 0 . 6 7 1}$ & 0.388 & -0.001 & -0.009 \\
Nitrate $\left(\mathrm{NO}_{3}\right)$ & 0.430 & 0.472 & -0.254 & -0.320 & 0.475 \\
Natrium $(\mathrm{Na})$ & $\mathbf{0 . 8 3 8}$ & 0.284 & -0.031 & 0.224 & -0.164 \\
Sulfate $\left(\mathrm{SO}_{4}\right)$ & -0.018 & 0.496 & $-\mathbf{0 . 7 0 3}$ & -0.174 & -0.057 \\
Carbonate $\left(\mathrm{HCO}_{3}\right)$ & -0.228 & $\mathbf{0 . 6 2 3}$ & -0.090 & $\mathbf{0 . 6 1 2}$ & -0.285 \\
\hline
\end{tabular}




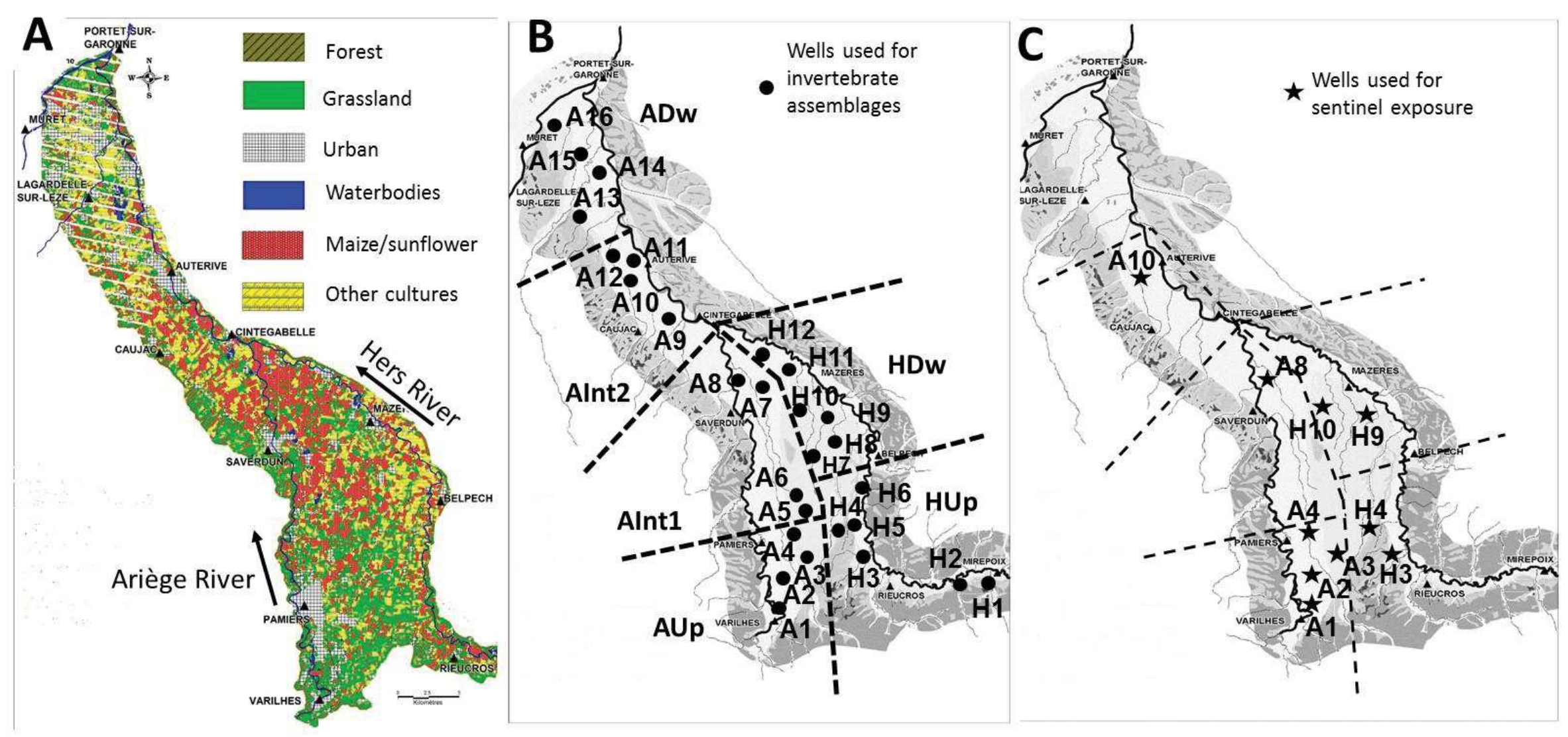

Figure 1. Land-use in the alluvial plains of the Hers and Ariège Rivers $(A)$ and location of sampled wells for the survey of stygobite assemblages (B) and sentinels exposure (C). Dotted lines: limits of the six sectors based on PROMINENT agricultural crops and practices. The land use was established using four satellite images (one for each season), except in the northern part of the plain where spring image was not available (noted here with yellow stripes). 

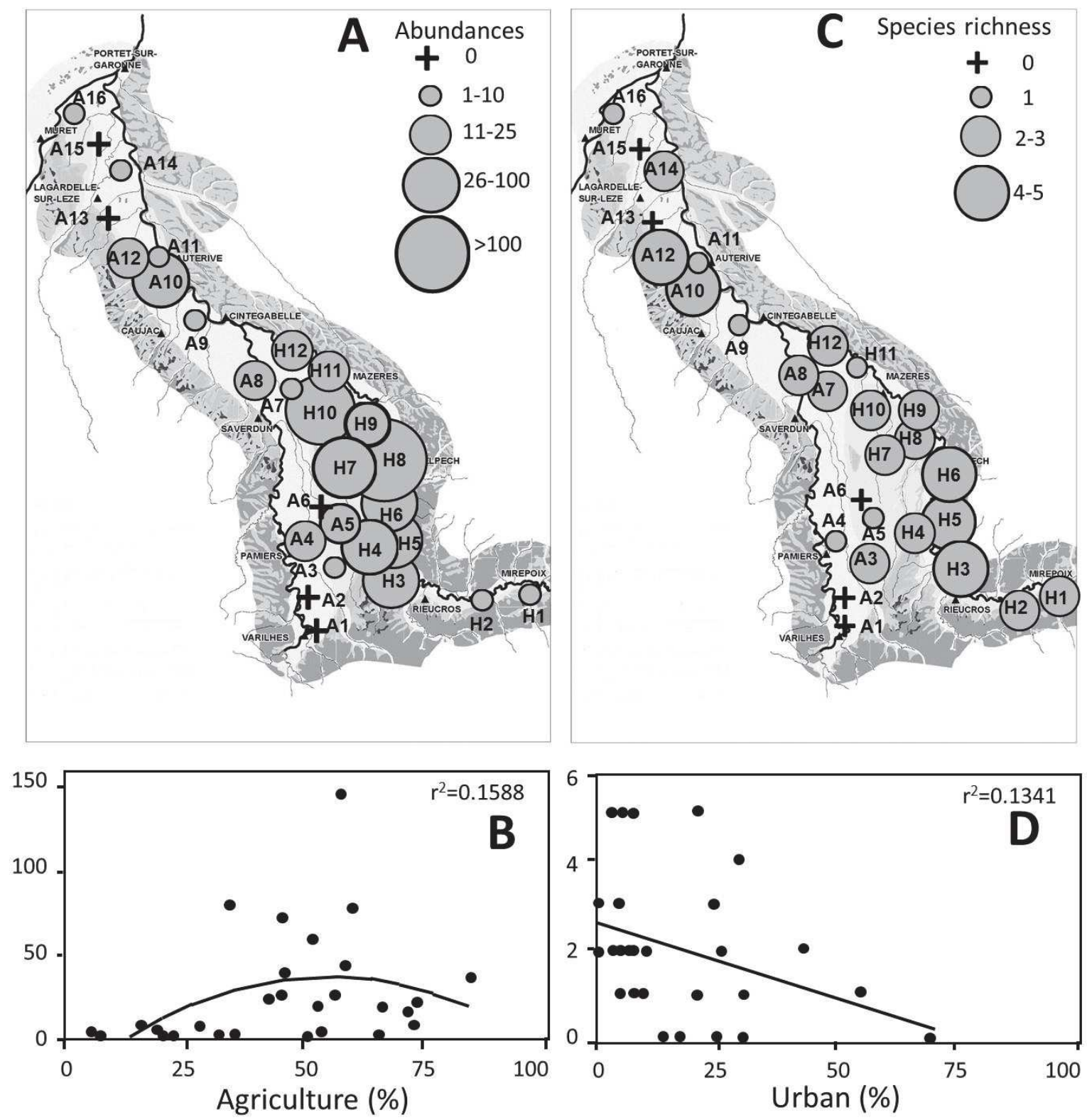

Fig 2. Abundances of stygobite as number of individuals per sample transformed in classes plotted on the sampling area $(A)$ and relation between abundances and the percentage of agriculture around the wells $\left(y=-0,019 x^{2}+2,095 x-22,05\right.$, B). Species richness as the number of species transformed into classes plotted on the sampling area $(C)$ and relation between richness and the percentage of urban area around the wells $(y=-0,0343 x+2,63, D)$. 


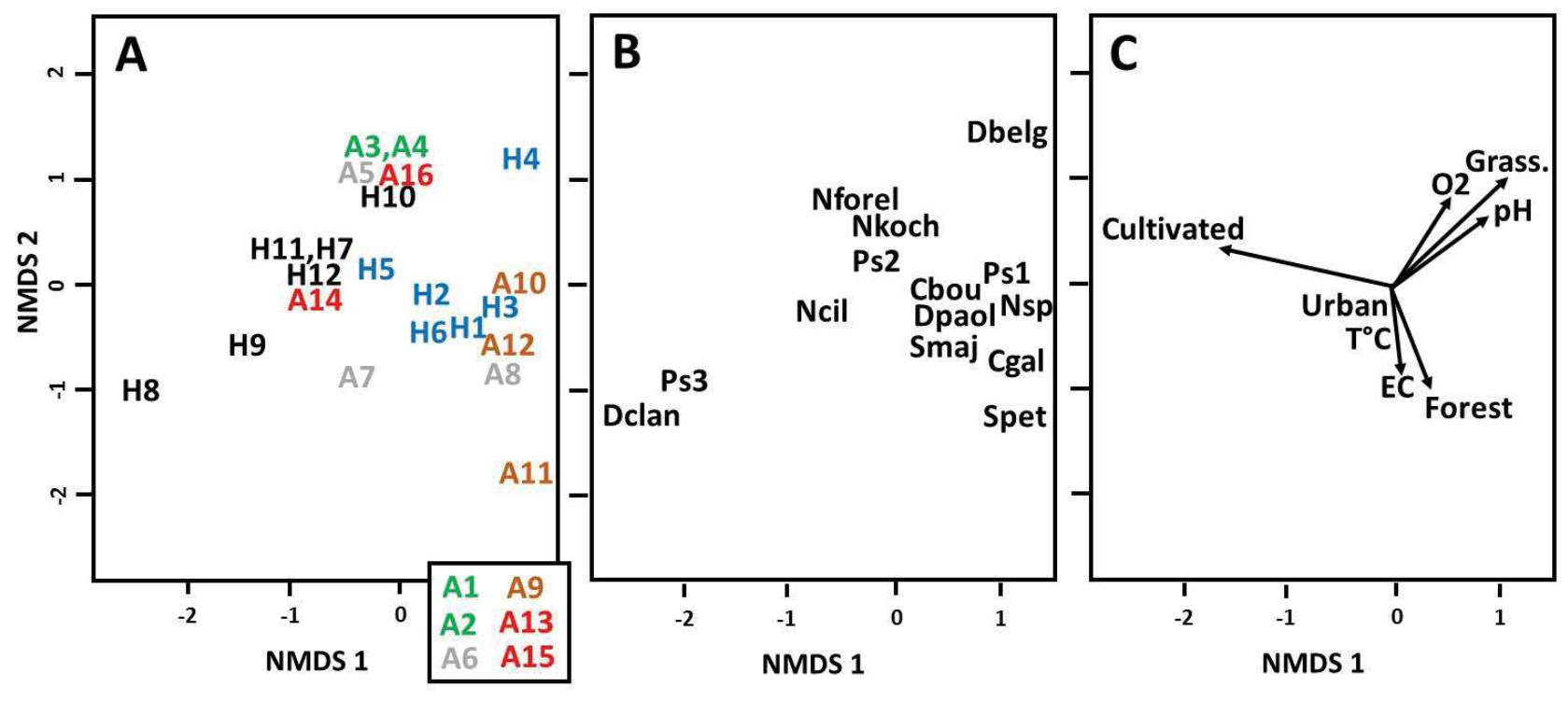

Fig. 3. NMDS of stygobite crustacean assemblages. The biplot of the first-two axes is separated into wells $(A)$ and species (B). Environmental characteristics are fitted to this biplot (C). Wells noted in blue are located in HUp, black n HDw, green in AUp, grey in Alnt1, brown in AInt2, red in ADw. The six wells noted in the box were excluded from the analysis because of the absence of stygobites. Cbou:

Candonopsis boui; Cgal: Ceuthonectes gallicus; Dbelg: Diacyclops belgicus; Dclan: Diacyclops clandestinus; Dpaol: Diacyclops paolae; Ncil: Niphargus ciliatus; Nforel: Niphargus foreli; Nkoch: Niphargus kochianus; Nsp: Niphargus sp.; Ps1, Ps2, Ps3: Pseudocandona sp. 1, sp. 2 and sp. 3; Smaj: Salentinella major; Spet: Salentinella petiti. Land use types included are the percentages of forest, cultivated area, grassland, and urbanized areas. Chemical characteristics included are dissolved oxygen $(\mathrm{O} 2)$, temperature $\left(\mathrm{T}^{\circ} \mathrm{C}\right)$ and electric conductivity $(\mathrm{EC})$. 


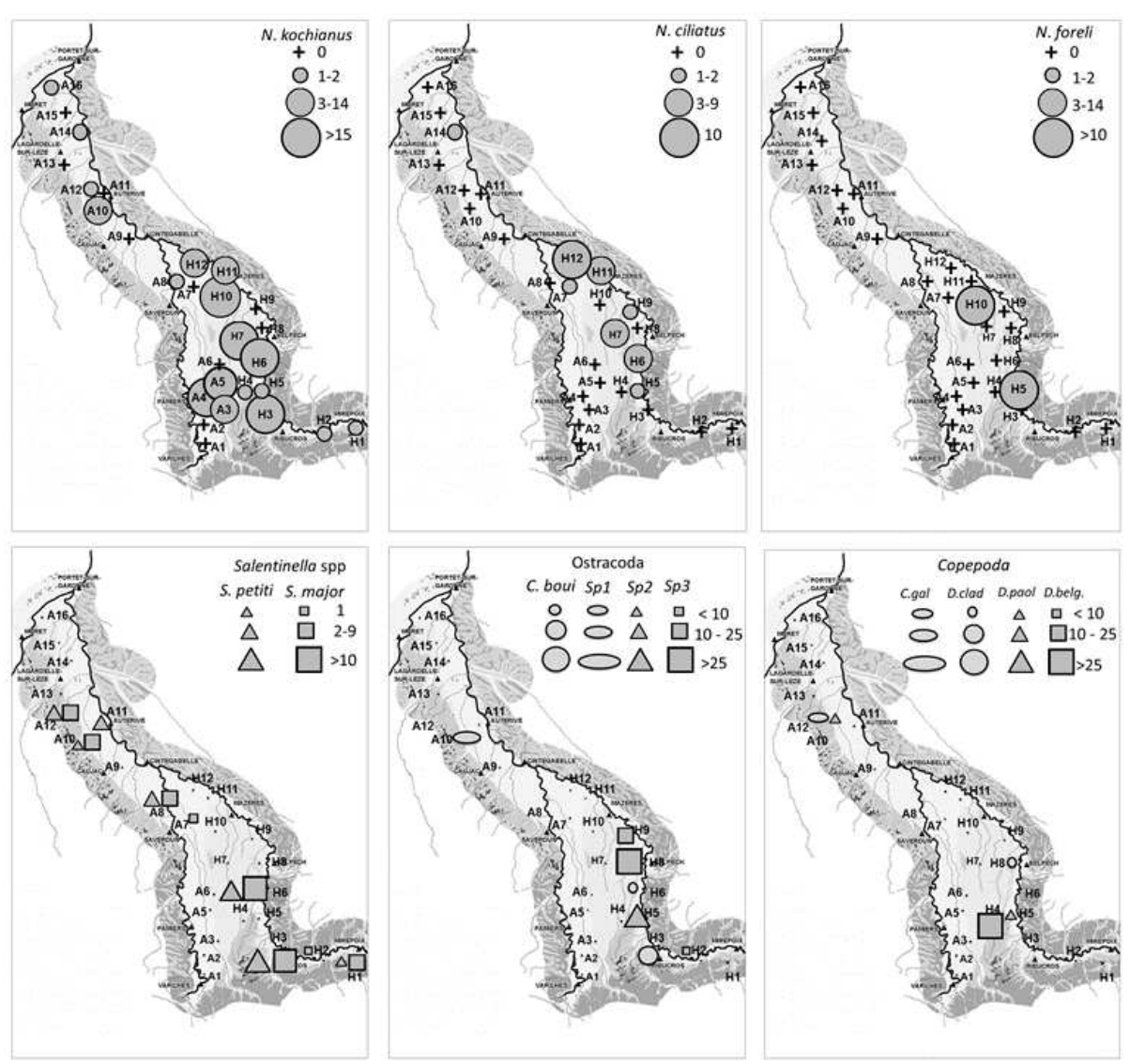

Fig. 4. Spatial distribution of stygobites crustaceans in the Ariège and Hers alluvial plains (as number of individuals per sample transformed in classes). Upper panels: Niphargus species. Lower panels: Salentinella spp; Ostracoda: Candonopsis boui, Pseudocandona sp. 1, sp. 2 and sp.

3; Copepoda: Ceuthonectes gallicus, Diacyclops clandestinus, Diacyclops paolae, Diacyclops belgicus 

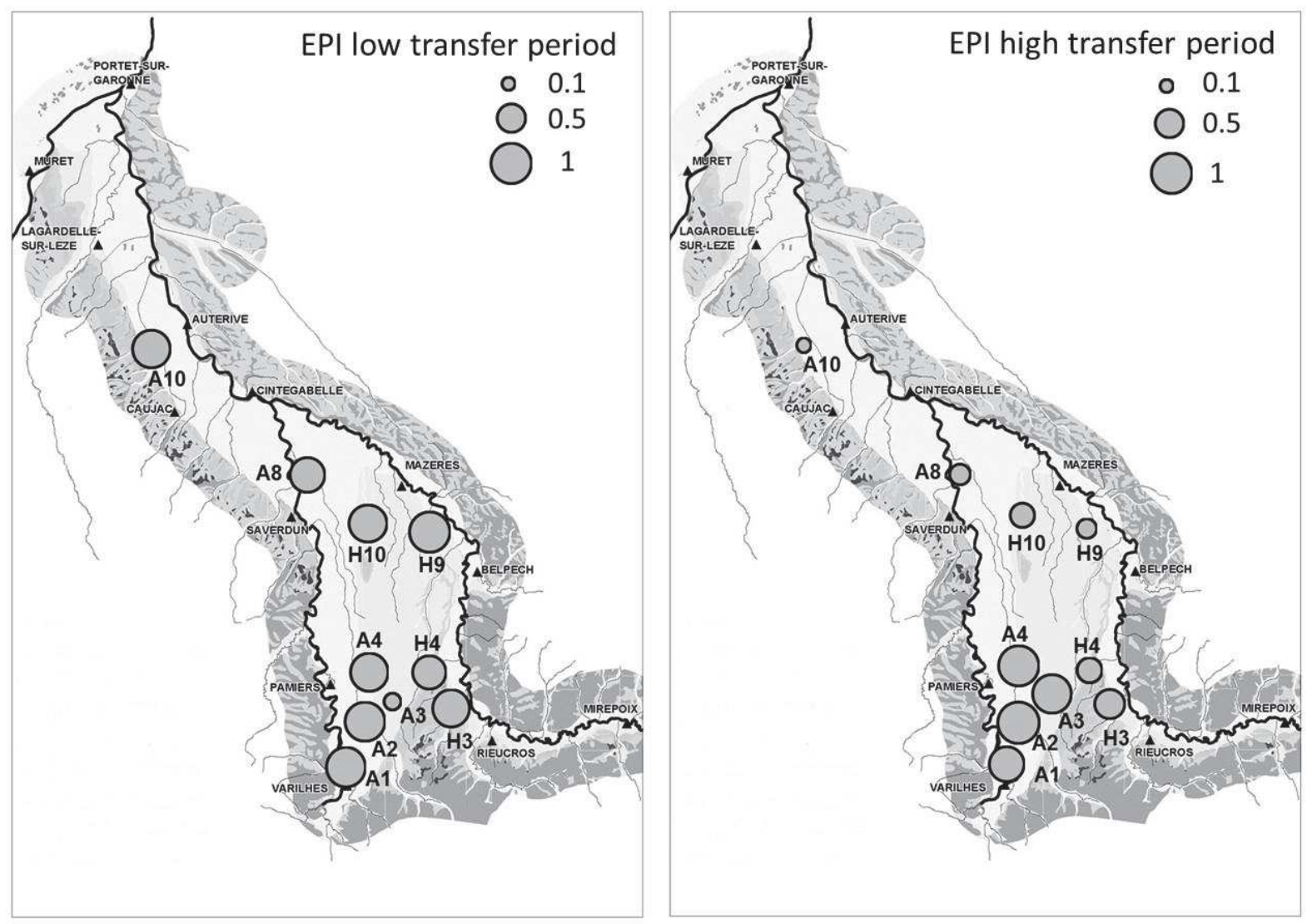

Fig. 5. Values of Ecophysiological Index (EPI) using Gammarus cf orinos sentinels after oneweek exposure to in situ groundwater during low transfer period (September 2012) with low agricultural impact and during high transfer period (July 2013), withhigh agricultural impact. EPI values are expressed as the ratio between in situ exposure and laboratory control ratios, ranging from zero (maximum in situ impact on amphipod ecophysiology) to 1 (minimal impact). 


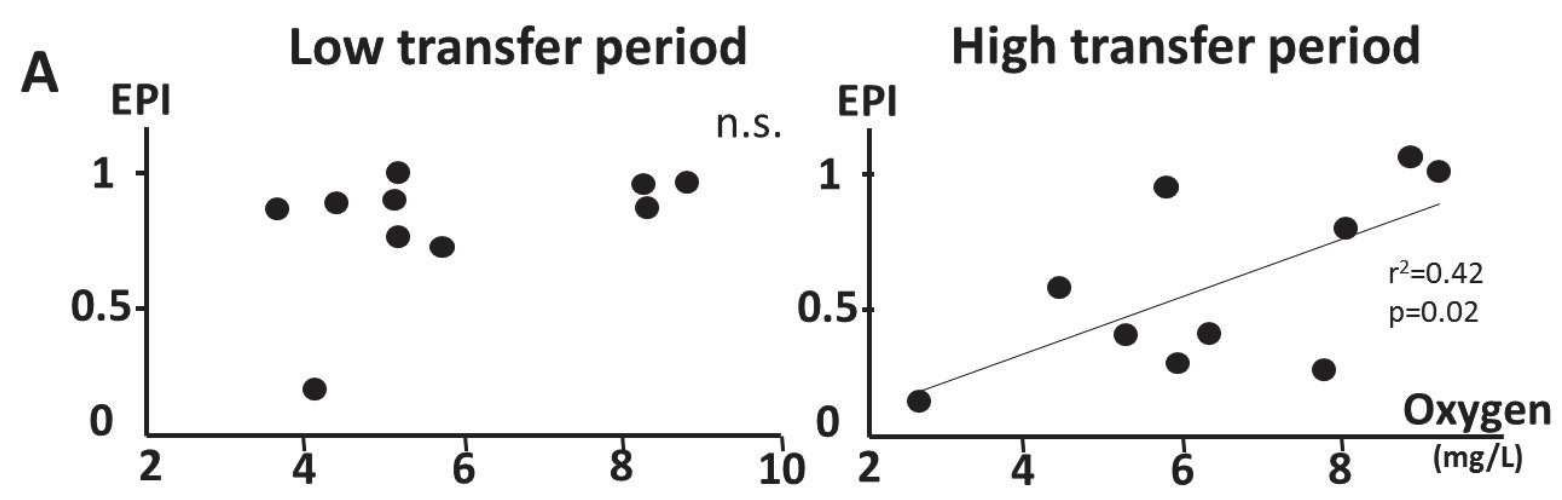

B EPI

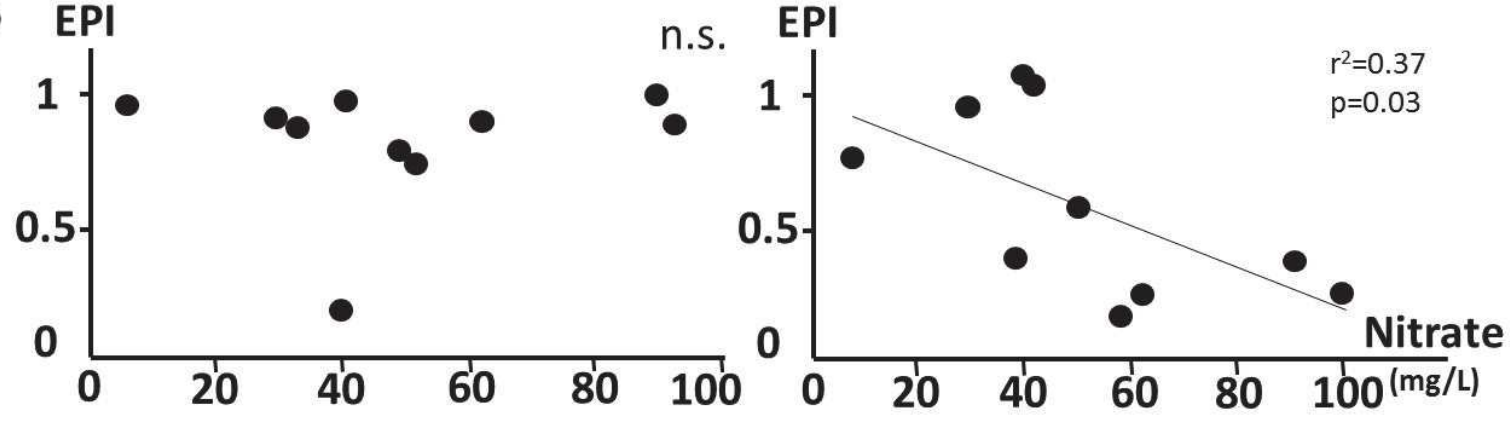

Fig. 6. Correlations between EPI and water chemical characteristics (A-Dissolved oxygen and B-nitrate concentrations) in period of low transfer (September 2012, left column, $n=10$ ) and high transfer periods (July 2013, right column, $n=10$ ). Regression line, $r^{2}$ and $p$-values are reported when significant (n.s. non-significant). 


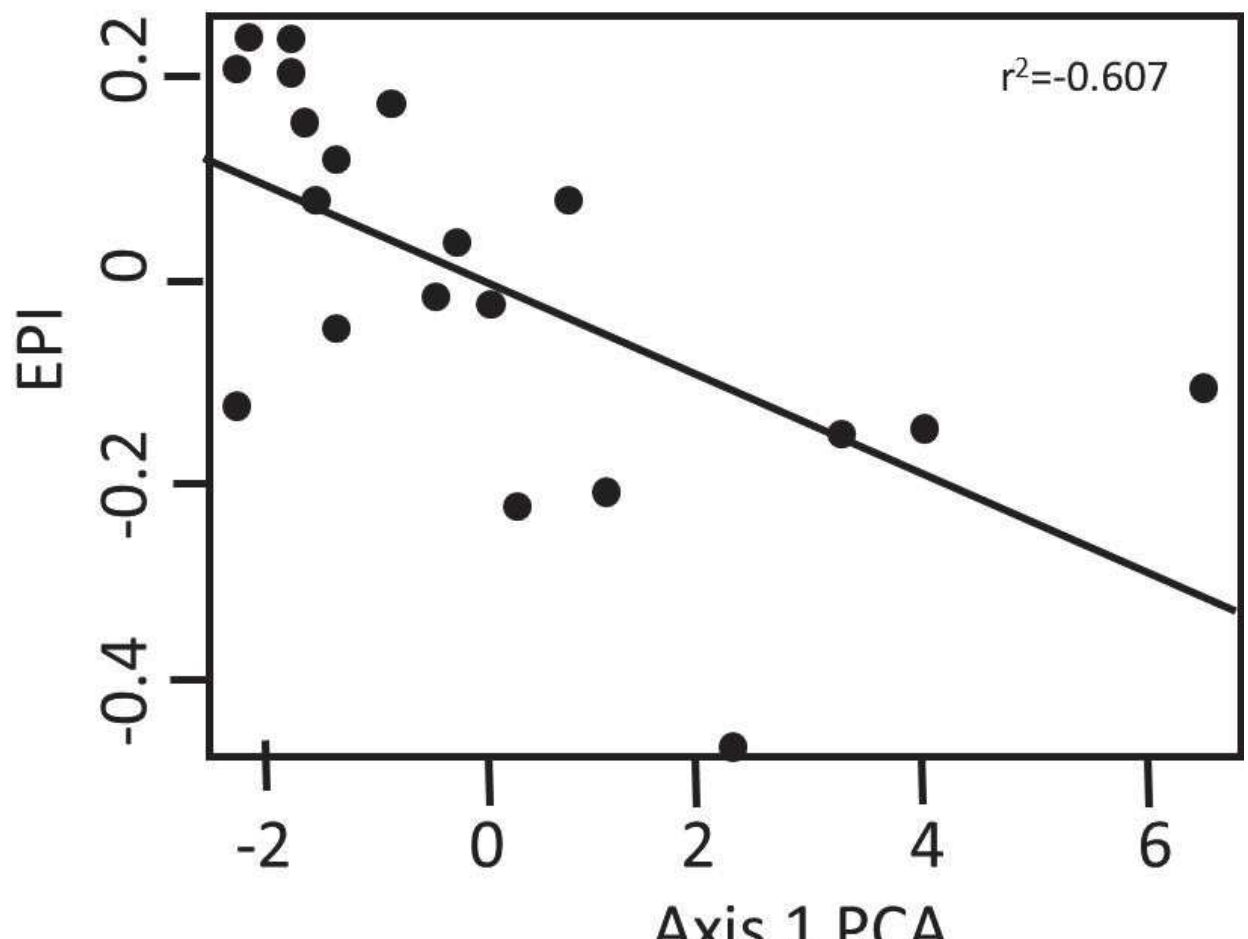

Fig. 7. Correlation between EPI and the first axis of a PCA performed on toxicants (period of high and low transfer cumulated, $n=20$ ). See Table 4 for variable loadings. EPI is represented as the residuals of a GLMM linking EPI to PCA axes 2 and 5, experimental sessions and the two resulting two-term interactions. 
Appendix 1: List of analysed compounds and their quantification limit

\begin{tabular}{|c|c|}
\hline & Quantification limit ( $\mu \mathrm{g} / \mathrm{L})$ \\
\hline Acetochlor & 0,005 \\
\hline Alachlor & 0,005 \\
\hline Ametryne & 0,005 \\
\hline Atrazine & 0,005 \\
\hline Chlortoluron & 0,005 \\
\hline Cyanazine & 0,005 \\
\hline Desethyl atrazine & 0,005 \\
\hline Desethyl terbuthylazine & 0,005 \\
\hline desisopropyl atrazine & 0,005 \\
\hline Desmetryne & 0,005 \\
\hline Diuron & 0,01 \\
\hline Hexazinon & 0,005 \\
\hline Isoproturon & 0,005 \\
\hline Isoproturon-1CH3 & 0,005 \\
\hline Isoproturon-2CH3 & 0,01 \\
\hline Linuron & 0,005 \\
\hline Metazachlor & 0,005 \\
\hline Metolachlor & 0,005 \\
\hline Prometryne & 0,005 \\
\hline Propazine & 0,005 \\
\hline Propyzamide & 0,005 \\
\hline Sebuthylazine & 0,005 \\
\hline Simazine & 0,005 \\
\hline Terbuthylazine & 0,005 \\
\hline Terbutryne & 0,005 \\
\hline Flusilazole & 0,005 \\
\hline Tebuconazole & 0,005 \\
\hline Tetraconazole & 0,005 \\
\hline OXA Metolachlor & 0,01 \\
\hline ESA Metolachlor & 0,01 \\
\hline OXA acetochlor & 0,01 \\
\hline ESA Acetochlor & 0,01 \\
\hline OXA Alachlor & 0,01 \\
\hline ESA Alachlor & 0,01 \\
\hline Glyphosate & 0,05 \\
\hline AMPA & 0,05 \\
\hline Deschloro Metolachlor & 0,005 \\
\hline
\end{tabular}


2-Ethyl 6-Methyl 2-Chloroacetanilide

0,005

2-Hydroxy Metolachlor

0,01

2-ethyl 6-methyl aniline

0,005

Metolachlor morpholinone

0,01

2-Ethoxy metolachlor

0,005

2-Chloro 2',6'-diethyl acétanilide

0,005

2,6-diethylaniline

0,005

dimethanamid

0,005 